Vol 41 (2016) No 184 105-129

\title{
What Do the Names of Higher Education Institutions in Turkey and the UK Imply?
}

\section{Armağan Erdoğan 1, Ebru Öztekin Bıyıklı 2, Tuba Demirkol ${ }^{3}$, Gökhan Ersoy ${ }^{4}$}

\begin{abstract}
Higher education is a growing field in which universities pursue better worldwide reputations. Although academic success is doubtless the most crucial element of a university's quality and worldwide image, university names also influence universities' functions and reputations.

This article is based on a project named "World Higher Education Institutions Name Map" at Social Sciences University of Ankara, Center for Higher Education Research. The project was primarily inspired by curiosity about which motives have influenced higher education institutions as they choose their names and whether it could be possible to detect any country-based tendencies in these choices. The data were gathered relying primarily on information elicited from the official websites of various countries' higher education institutions. This article will focus on preliminary findings based on the data and will provide a comparative analysis of the names of higher education institutions in Turkey and the United Kingdom. The United Kingdom has been chosen because it has several long-established universities and is one of the leading countries in the field of higher education. Turkey has been included because it has a variety of higher education institutions ranging from the old to the very recent.
\end{abstract}

Keywords

DOI: 10.15390/EB.2016.6159

\section{Introduction}

Unlike lower levels of education, higher education has a substantial impact on both individuals and societies (White, 1997). Higher education evolved from being a privilege for elite and restricted beneficiaries to servicing a mass population after the 20th century. Higher Education Institutions (hereafter HEIs) are complex institutions that are fundamental to cultural life, economic prosperity, social cohesion and national identity (Anderson, 2006). With the technological and global developments of the 21st century, higher education has become integrated with nations' economic plans because it prepares human resources for the conditions of the 21st century (Cortese, 2003). Students, parents, employers and other related stakeholders seek affiliation with more prestigious institutions. One question that arises relates to the factors that contribute to the prestige of HEIs.

\footnotetext{
1 Social Sciences University of Ankara, Center for Higher Education, Turkey, armagan.erdogan@asbu.edu.tr

2 Social Sciences University of Ankara, Language Centre, Turkey, ebru.oztekin@asbu.edu.tr

${ }^{3}$ Social Sciences University of Ankara, Language Centre, Turkey, tuba.demirkol@asbu.edu.tr

${ }^{4}$ Social Sciences University of Ankara, Information Technology Department, Turkey, gokhan.ersoy@asbu.edu.tr
} 
Therefore, higher education is a field of competition within and between countries and regions (Van der Wende, 2009). In this competitive arena, HEIs are engaged in an endless struggle to construct a positive image for themselves (OECD, 2007). Along with academic success and educational quality, HEIs continue to improve their market image by utilizing other factors such as campus facilities, corporate identity branding and naming.

Some researchers have worked on HEIs' institutional image, corporate branding and marketing strategies (Hemsley-Brown \& Goonawardana, 2007; Kennedy, 1997; Mourad, Ennew, \& Kortam, 2011; Pfoertsch, Linder, Beuk, Bartikowski, \& Luczak, 2007; Slaughter \& Leslie, 1997). Considering that in recent decades higher education has been described more as a "market" in which institutional profit parallels institutional prestige and the number of students, it would be interesting to learn whether HEIs have special preferences when selecting a name (Landrum, Turrisi, \& Harless, 1998; Neumark, 2012; Van Riel \& Balmer, 1997; Webster \& Keller, 2004; Waeraas \& Solbakk, 2009). Some studies discuss this aspect by comparing HEIs to companies that change their names for marketing purposes (Slaughter \& Leslie, 1997; Ivy, 2001). Of the several elements that comprise an HEI's corporate image, its name contributes to the desired public image.

As a general term, "institutional image" refers to different sectors and is defined as "the overall impression made on the minds of the public about an organization" (Barich \& Kotler, 1991). Following this line of scholarship, an HEI's image is defined as "the sum of all beliefs an individual has towards the [HEI]" (Landrum et al., 1998). Institutional image is also defined as comparing and contrasting various aspects of an organization (Kennedy, 1977). In higher education, the image of an HEI relates to various institutional attributes such as name, logo, tagline, color palette, facilities, former students, course offerings, academic reputation, and public behavior (Alessandri, 2001), along with the HEI's architecture, ideology, tradition and variety of products or services (Nguyen \& LeBlanc, 2001). Institutional image plays an important role in determining the institution's popularity among scholars, students and even parents (Nguyen \& LeBlanc, 2001). Naming creates the institution's first image and is a tool for influencing its perceived credibility, prestige and attractiveness in the market (Peluso \& Guido, 2012; Doğan, 2009; Zaghloul, Hayajneh, \& Almarzouki, 2010). Accordingly, it would not be wrong to say that scrutinizing the names of HEIs can give us information about their images, branding and identity strategies.

This article will investigate the names of HEIs in Turkey and in the UK retrieved from the World Higher Education Institutions Name Map (WHEINM) project conducted by Social Sciences University of Ankara. WHEINM is an ongoing, dynamic study that was initiated with the goal of collecting data on the names of HEIs in various countries and then investigating whether HEIs around the world displayed any remarkable similarities, differences and tendencies with respect to their name preferences. Relying on the fact that this aspect of HEIs is an under-researched area in the academic field, we assumed that this project would contribute to identity strategies in higher education studies. We narrow our focus to categories of names by relying on an intuition that institutional names are among the factors that contribute to HEIs' image, target and prestige. Additionally, the content of the names will be evaluated by considering HEIs' identities, hinterlands, and relations. The name map of the world's HEIs to be prepared at the end of this project will also provide other indicators of HEIs' identities, including foundation year, location, student enrollment, and web address. It is planned for this comprehensive map to provide open access and dynamic multilingual data to investigate naming tendencies among HEIs worldwide. 
That said, this article utilizes the data from only two countries from the WHEINM projectTurkey and the UK - to shed light on the similarities and differences among HEI names in the two countries. The UK and Turkey have been chosen for this article because the former is one of the world's leading countries in higher education, with long established and prestigious HEIs, whereas the latter has a recently enlarged HEI system with numerous old and newly established HEIs. The study will investigate and compare the naming strategies (if any) under two indicators. First, the most frequently used names of the HEIs in each country will be investigated to determine the overall trend in naming strategies. Second, the study considers foundation date as another indicator. To examine whether a country's social, historical and political changes a country may have resulted in a noticeable strategy in name-giving trend related to HEIs, the HEIs in both countries will be examined with a reliance on foundation dates, which were grouped based on certain time intervals.

In this study, names of HEIs as part of their branding and identity building strategies were scrutinized via a name-mapping project. Naming the HEIs seems to be an under-researched topic in higher education studies and therefore little work specifically addresses HEIs' names. However, we believe that the project is an important asset to investigate how HEIs' names define and brand the institutions while they product knowledge and technology.

\section{Methodology}

The project, titled World Higher Education Institutions Name Map (WHEINM), has been planned and implemented by the Center for Higher Education Research at the Social Science University of Ankara. It is a dynamic study in which the demographic features of HEIs (native name, foundation date, type, student population, census year, location, and web address) around the world are collected and their names are divided into meaningful units and tagged according to their meaning. The project was set up and carried out by a large research group for one year. Under the project leader, two coordinators, one system administrator, and 18 researchers with a good command of various languages worked together to tag HEI names. The project covered 68 countries and the researchers tagged the names of 12,967 HEIs. We opted for non-convenience sampling with respect to the countries that would be involved in the project. In other words, we covered these countries because they were available to us because of the researchers' language proficiency. We eliminated those countries for whose language we did not have a proficient researcher.

First, the HEIs to be analyzed were defined by referring to formal sources, if available, such as the web pages of the educational ministry or other formal foundation in charge of HEIs, or other international sources that provide a comprehensive list of selected HEIs such as the UNESCO and International Association of Universities (IAU) lists. ${ }^{1}$ After having identified the HEIs to be analyzed, a computer program, the interface of which was published on a web page (http://unitag.asbu.edu.tr/home), was created to gather, compare and analyze the necessary information. This program primarily served two functions: (1) to create representations of institutional identities by collecting necessary demographic information such as foundation date, student population, and geographical position; and (2) to classify the names of these institutions under related categories. The entire data-collection process of the WHEINM project and therefore of this study took nearly two years. Three stages were followed during the data-collection process. The initial stage was used to form a comprehensive list of HEIs, the second stage involved the main tagging process and the final stage was reserved to performing a final data check by controlling the data's reliability and the compatibility of the researchers' tagging choices.

\footnotetext{
${ }^{1} \mathrm{http}: / /$ www.unesco.org/new/en/education/resources/unesco-portal-to-recognized-higher-education-institutions/; and http://www.whed.net/home.php
} 
Because this study was data driven, these categories were formed and continuously reshaped during the process of forming the need-based tag database. Three gradual steps were followed in organizing these categories. The main category was defined by relying on the content of names and to the greatest extent possible, this upper-level category was labeled with an inclusive name. Next, secondary subfolders were defined under the main folders. These first two upper-level folders aimed to lead the researchers through their category choices and pinpoint the most appropriate label for the HEI names. The point here was that the researchers could not use these folder names to tag selected institutions (the words that the researchers could use for defining the items in the institutions' names are referred to as tag and the action was referred to as tagging) ${ }^{2}$. For example, one of the main folders was Field of Science. Several secondary-level subfolders were defined for this main folder, including Social Sciences, Natural Sciences, and Arts. Under these folders, all related tags were provided in the computer program not only to enable the researchers to choose the most related, appropriate tag for the target names but also to avoid the double tagging of a single name under different folders.

Another point to discuss here is the process of choosing inclusive labels for main folders. Although the organization of the folders was described in a top-down fashion, their creation took place in a bottom-up style. As stated above, the folders were created relying on data consisting of the selected institution names. The creation of folders was a data-driven process in which the names were suggested, accepted, and revised relying on the HEIs' names. For instance, upon encountering specific scientific fields such as Economics or Management, we created a folder name of Fields of Science, which was comprised of main branches in a hierarchical fashion. Ten main folders emerged throughout the data analysis as follows:

Linguistic Items: Includes function words that have no independent meaning such as prepositions, pronouns, and conjunctions but that are included in HEIs' names (such as of, in, the) and climate

Concept: Includes a wide array of words related to various concepts such as culture, career,

Identity: Includes words affiliated with a specific religion and/or ethnicity

Abbreviation: Includes abbreviated names of companies, groups, or individuals

Location: Includes words referring to geographical areas (mountain, river, valley, etc.), physical entities/buildings (castle, bridge, museum, etc.), and place of residence (country, city, village, etc.)

Type of HEI: Includes words specifying the type of institution such as college or university

Number/Date: Includes numbers and dates, all of which have some cultural or historical meaning

Group/Community: Includes any type of community such as a formal institution, historical community, or corporation

Famous People: Includes people who have historical, religious, or political importance

Fields of Science: Includes sub-branches of scientific fields such as natural sciences, social sciences, and fine arts (which were determined relying on OECD 2007 Fields of Science and Technology Classification) (OECD, n.d.)

\footnotetext{
${ }^{2}$ See the appendix for the detailed list of the folders, subfolders and tags.
} 
Ongoing revisions to these tag categories were actualized relying on the feedback of the researchers involved in the study. Because of the dynamic and data-driven nature of the project, the coordinators both decided to make changes to the tags and provided continuous guidance to the researchers about revisions to the system. Each of the selected institutions was appropriately entered into the computer program by the researchers and the database was completed. The final version of the program was designed to allow the calculation of descriptive statistics for each country, making it possible to compare the names of the institutions in those countries.

As stated above, for the scope of this study, the names of the HEIs in the UK and Turkey were compared. The United Kingdom has been chosen because it has several long-established universities and is a leading country in the field of higher education. Turkey has been included because it has a variety of HEIs ranging from the old to the very recent and is a rapidly growing system. This comparison was actualized around two indicators in both countries: (1) the frequently used name categories; and (2) the HEIs' foundation dates.

The main aim of this article is to examine the names of HEIs around the world to answer the following questions:

Are there any national or cultural similarities and/or differences in the most frequently detected tags in the HEI names of both countries'?

Is it possible to detect a noticeable relationship between different time intervals and HEI names in both countries?

To increase the strength of the methodology, the universe of the project was narrowed to HEIs that offer bachelor's and/or graduate degrees both in Turkey and the UK because these two countries might differ in relation to the structures of their higher education systems. Having defined the scope of the study, several other steps were taken for contextual analysis.

\section{Main Findings}

Overall, 302 HEIs in the UK (England, Scotland, Wales and Northern Ireland) and 179 in Turkey were included in this study. The central body coordinating the universities in the UK is Universities UK. It should be noted here that the two countries' higher education systems differ in many ways. For example, whereas admission to higher education in the UK is operated by UCAS (Universities and Colleges Admission Service), in Turkey YÖK (Council of Higher Education) and ÖSYM (Student Selection and Placement Center) are responsible for defining and operating the access process (Çetinsaya, 2014). The majority of the UK's HEIs are funded by the government, but there are alternative providers from for profit or non-profit private enterprises. In Turkey, most HEIs are government financed; in addition, numerous non-profit foundation HEIs were established by law after 1982. UK HEIs are approved by the Privy Council and can use the title university after its approval; however, there is a variety of HEIs, which are regulated by different laws depending on their foundations and structures (British Council, n.d.; Europass, n.d.; Universities UK, 2014; Universities UK, 2015). In Turkey, however, HEIs are established by law after YÖK's suggestion to the ministry and Cabinet approval. Therefore, the HEI-naming process in both countries differs. This study's main findings focus on comparing the name tags while avoiding making bold generalizations about the two systems. 


\section{The Most Frequent Tags Detected in the Names of HEIs \\ A) Higher Education Institutions in Turkey}

There is an immense amount of growth in the number of Turkish higher education institutions (HEIs) to date. Currently there are 193 HEIs in Turkey (YÖK, n.d.). However, the names of 179 HEIs in Turkey have been analyzed in this project as the universe was defined in 2014. Those HEIs included both public and non-profit foundation institutions. The following analysis presents the most frequently used tags that have been detected in the names of these institutions. The aim of this primary analysis is, if possible, to provide a general impression of the prominent tendencies in choosing HEI names in both countries.

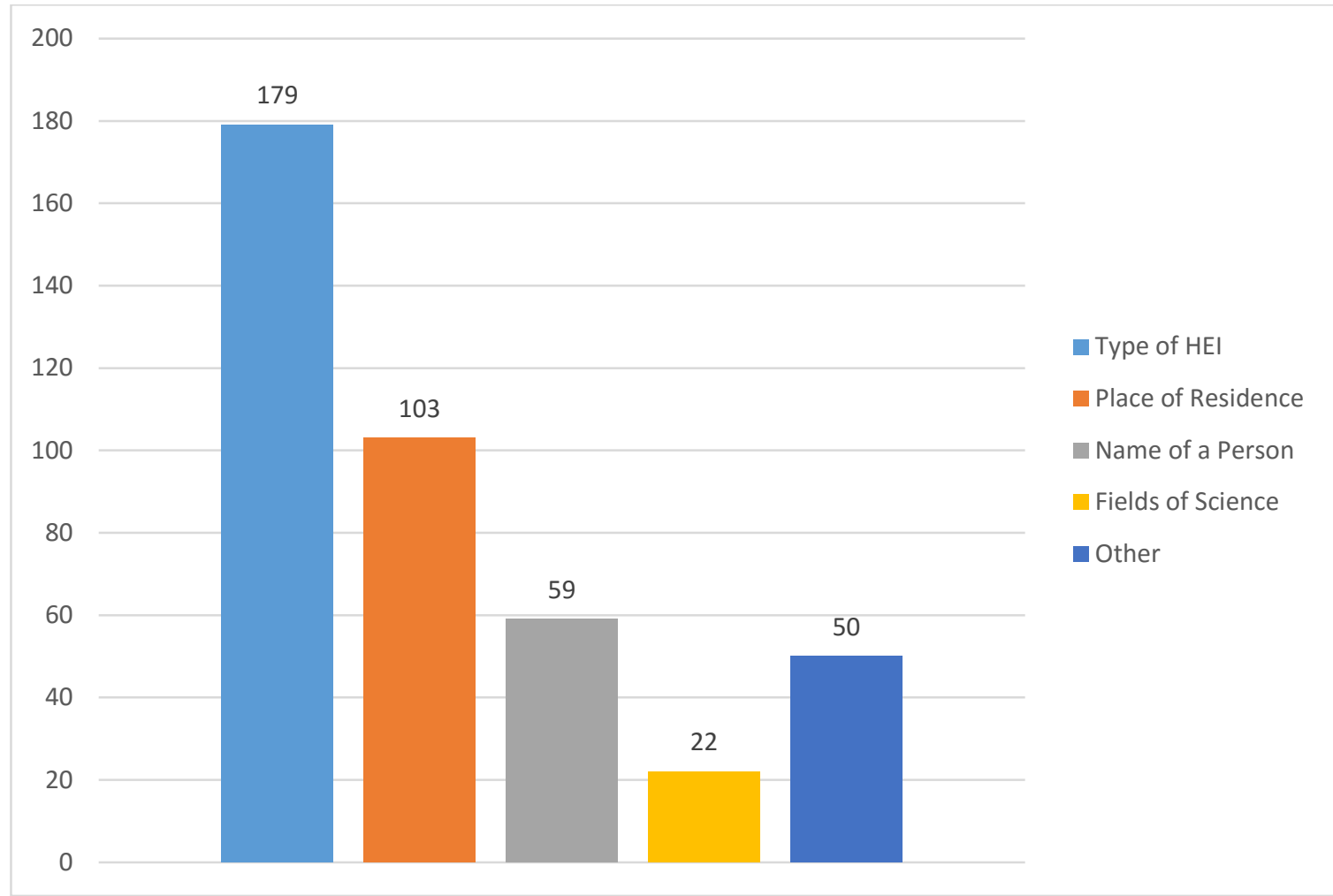

Figure 1. Distribution of the Most-frequent Tags in the Names of HEIs in Turkey

As it is shown in Figure 1, the most frequently used folders in the names of HEIs in Turkey were 'Type of HEI', 'Place of Residence', 'Name of a Person', and 'Fields of Science'. The most frequently used folder was 'Type of HEI' (179); it is important to remember that 'Type of HEI' is going to appear as the most frequently used folder in each analysis because it is indispensable for each HEI name to indicate what type of institution it is, regardless of country. Thus, considering that each HEI must include a word to describe its type, each analysis will result in 'Type of HEI' to appear as the most frequently used folder. In the 'Type of HEI' folder for the Turkey analysis, the university tag was seen as prominent, applying to a large majority, namely, 173 institutions. This shows that majority of the HEIs in Turkey are established as universities and there is not a considerable variety of institutions because only a few HEIs are academies or institutes. 'Place of Residence' (103) was another folder that appeared quite frequently (77 times) and it was primarily comprised of city names. This folder is significant, showing that in Turkish higher education, most HEIs' names include their cities. Additionally, when it is checked to determine which city name is used the most by HEIs, it is clear that Istanbul predominates, having been used in the names of 17 HEIs. Another frequently used folder was 'Name of a Person' (59), which mostly included the names of 22 politicians (i.e., Abdullah Gül University and İnönü University, Recep Tayyip Erdoğan University), 22 university founders (i.e., İhsan Doğramacı Bilkent University, Koç University, Abant İzzet Baysal University), three soldiers (i.e., Çankırı Karatekin University, Gaziosman Paşa University, and Piri Reis University), three artists (i.e., 
Mehmet Akif University, Mimar Sinan Fine Arts University, and Namık Kemal University), two public heroes (i.e., Kahramanmaraş Sütçü İmam University and Osmaniye Korkut Ata University), three philosophers (Hacı Bektaşı Veli, Mevlana, and Ahi Evran), two scientific figures (Biruni and Ktip Çelebi University), one academic (Sabahattin Zaim University) and one religious figure (i.e., Bilecik Şeyh Edebali University). Although it was not as popular as these categories, the 'Fields of Science' folder (22) was also observed to be used frequently and 'Engineering and Technology' was the most popular subfolder, detected 11 times out of 22 (i.e., Adana Science and Technology University, Istanbul Technical University, and Izmir Institute of Technology).

\section{B) Higher Education Institutions in the UK}

The most frequently used tags in the names of UK HEIs were listed under the 'Type of HEI' folder (341), as seen in Figure 2. Within the folder, the most prominent tags were university (160) and college (75), respectively. Next came the subfolder titled 'Place of Residence' (218), with the city name (i.e., University of Sheffield) and capital name (i.e., City University London) tags used the most frequently (91 city name, 44 capital name). There were also 26 institutions tagged as village/ town/riding (i.e., University of Warwick). In third place was the 'Fields of Science' folder (116), in which most of the schools were tagged as 'Fine Arts' (54) and 'Social Sciences' (34), both of which were subfolders and composed of related tags. Two examples are Guildhall School of Music and Drama and Grafton College of Management Sciences. 'Name of a Person', 'Geographical Area' and 'Various Concepts' folders were used 38, 21 and 21 times, as in Saint George's University of London, Queen Margaret University, South Eastern Regional College, and Wirral Metropolitan College, respectively. The frequently used tags in the 'Name of a Person' folder were founder (15) and religious figure (10). The total of rarely used tags that do not fit easily into any category can be seen in Figure 2 under the 'Other' title (51).

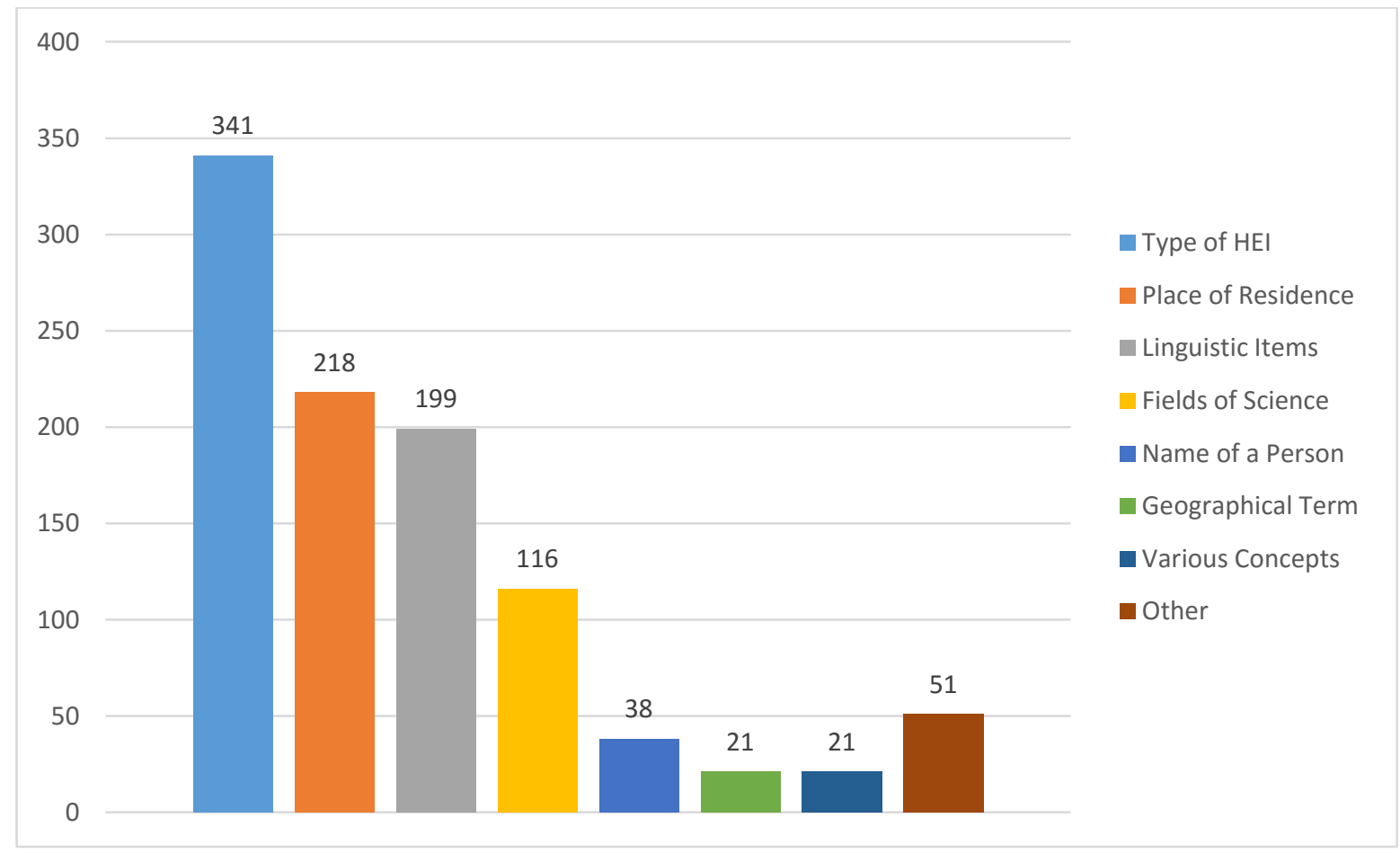

Figure 2. Distribution of the Most-frequent Tags in the Names of HEIs in the UK 
Overall, when we compared the commonly used tag folders in both countries, we observed some meaningful differences. Whereas in Turkey it was possible to group tags under three main folders ('Place of Residence', 'Name of a Person', and 'Fields of Science'), for the UK, we encountered a more dispersed grouping. In the UK, 5 main folders were needed to group the names ('Place of Residence', 'Fields of Science', 'Name of a Person', 'Various Concepts' and 'Geographical Area'). Additionally, in both countries 'Type of HEI' was the most commonly used folder. For Turkey, university was the most employed type whereas in the UK, university and college were both used extensively. The content of the 'Fields of Science' folder also differed. In Turkey, the prominent subfolders were 'Service' and 'Engineering', whereas in the UK 'Fine Arts' took the lead. Moreover, politician and founder were very frequent tags in Turkey whereas in the UK, religious figure was used more than politician. One last important difference was that because of the linguistic structure of English, for the UK we found many words tagged as 'Linguistic Items' such as "the, in, of etc.", which was an underused folder in Turkey's data. The following part will present a more detailed analysis that was performed by considering the foundation dates of selected HEIs in Turkey and the UK.

\section{HEIs According to Foundation Date}

To explore whether specific naming preferences or tendencies could be detected in Turkey and the UK depending on the HEIs' foundation dates, we attempted to analyze the most frequently used tags in certain time periods. To achieve this, specific time periods were first determined for both of the countries and HEIs were classified based on those time intervals. Because the development of HEIs in Turkey and the UK were influenced by different historical events, the time periods around which the selected HEIs were grouped were country-specific.

\section{A) Time Intervals in Turkey}

HEIs in Turkey were classified into four groups. The first group was the HEIs established before 1980; the second group was the HEIs established between years 1980-1992; the third group was the HEIs established between 1993 and 2006; and the fourth group was the HEIs established after 2006. This classification was realized based on various indicators such as significant periods in the history of the higher education or enlargement of the system. When the new higher education law (No. 2547) was approved and Council for Higher Education (YÖK) was established in 1980, there were 27 HEIs. In 1992, 29 new HEIs, particularly in rural areas and medium-size cities, were established. In the third category, which covers the years between 1993 and 2006, another 40 HEIs were founded. Finally, after 2006 there was a significant increase of 80 newly founded HEIs, which means that new public and foundation HEIs were established in a relatively short period of time (Günay \& Günay, 2011).

\section{1' Period: Before 1980}

When we examine the first period, we encounter 27 HEIs established before 1980. As shown in Figure 3, frequent tags used in the names of these HEIs belonged to four folders or subfolders, namely, 'Fields of Science', 'Geographical Area', 'Place of Residence', and 'Type of HEI'. When these main folders were examined individually, it was seen that most of the HEIs founded during this interval carried the title of university, although there were four academies (i.e., Gülhane Military Medical Academy, Turkish Naval Academy, Turkish Military Academy, and Turkish National Police Academy). The next frequent tag category was 'Fields of Science'; the fields in this category included Engineering (i.e., Yıldiz/Karadeniz/Middle East/ Technical University), Service (i.e., Military and Police), Medicine (i.e., Gülhane Military Medical Academy), and Fine Arts (i.e., Mimar Sinan Fine Arts University). It can be stated that a diversity of HEI types was very noticeable in this period, whereas mostly "universities" were established in the later periods. 


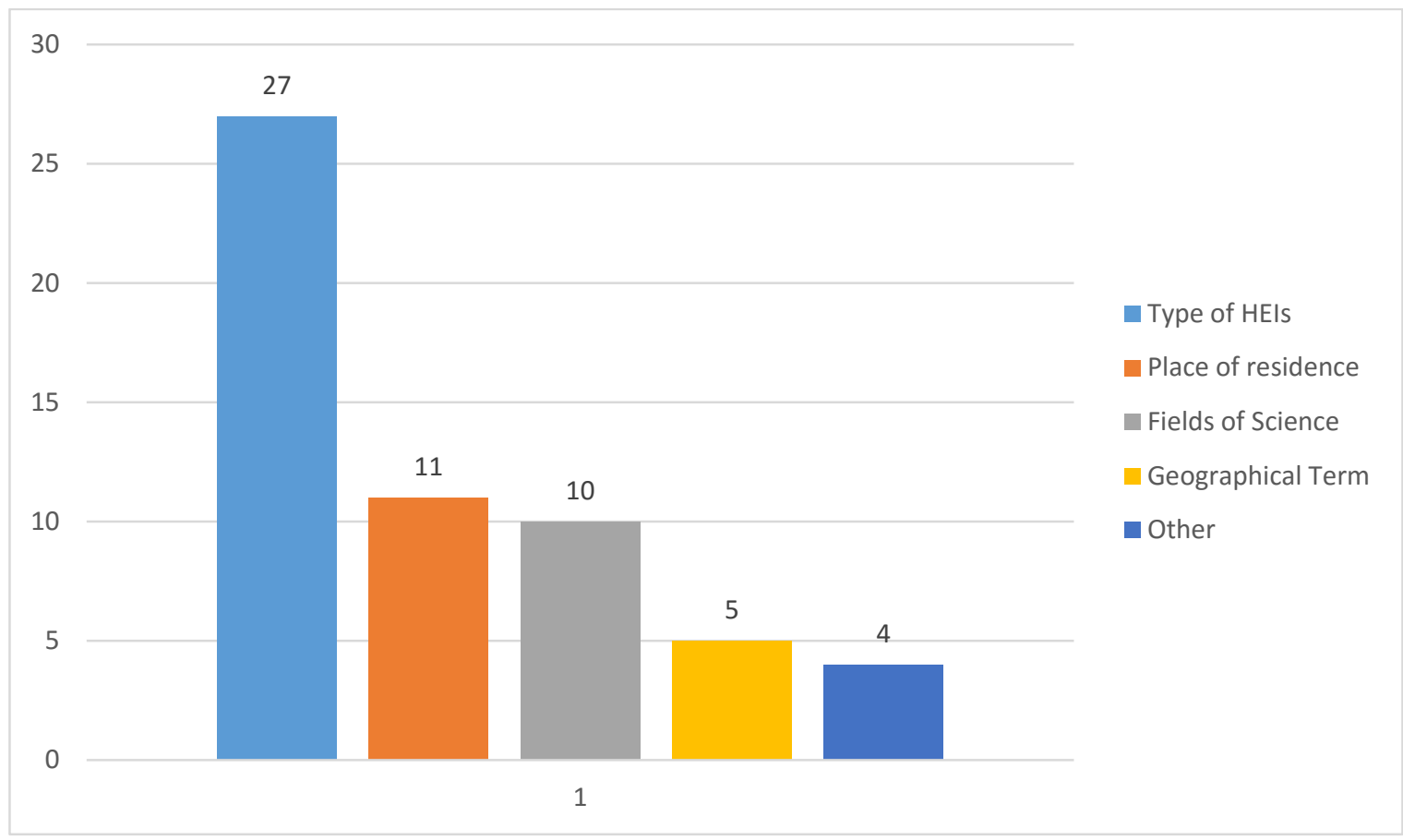

Figure 3. Distribution of the Most-frequent Tags in the Names of HEIs Founded in Turkey before 1980

'Place of Residence' was another frequently used folder and it was seen that half of these tags were the names of geographical regions in Turkey (i.e., Ege University, Marmara, Middle East, Anatolian, and Karadeniz Technical University). If we ignore İstanbul University and İstanbul Technical University, we can claim that for the names of HEIs with earlier foundation dates, geographical regions were preferred to city names. This tendency may be explained by the fact that there were not many HEIs in Turkey during that period and geographical regions used in the names may signal that those HEIs were founded to serve the needs of students from wider areas instead of being associated with specific cities. The last category was also a related tag, 'Geographical Area'. The analysis showed us that there were five geographical terms in the names of HEIs belonging to this group. These geographical terms were the names of rivers (Frrat \& Dicle University), mountains (Erciyes University, Uludağ University), and plains (Çukurova University) in Turkey. This finding again signifies that regional values were emphasized instead of local/city concepts.

$2^{\text {nd }}$ Period: 1980 - 1992

The second period defined in Turkey for grouping HEIs according to foundation dates covered the years between 1980 and 1992. Overall, 29 HEIs in Turkey fell into this group.

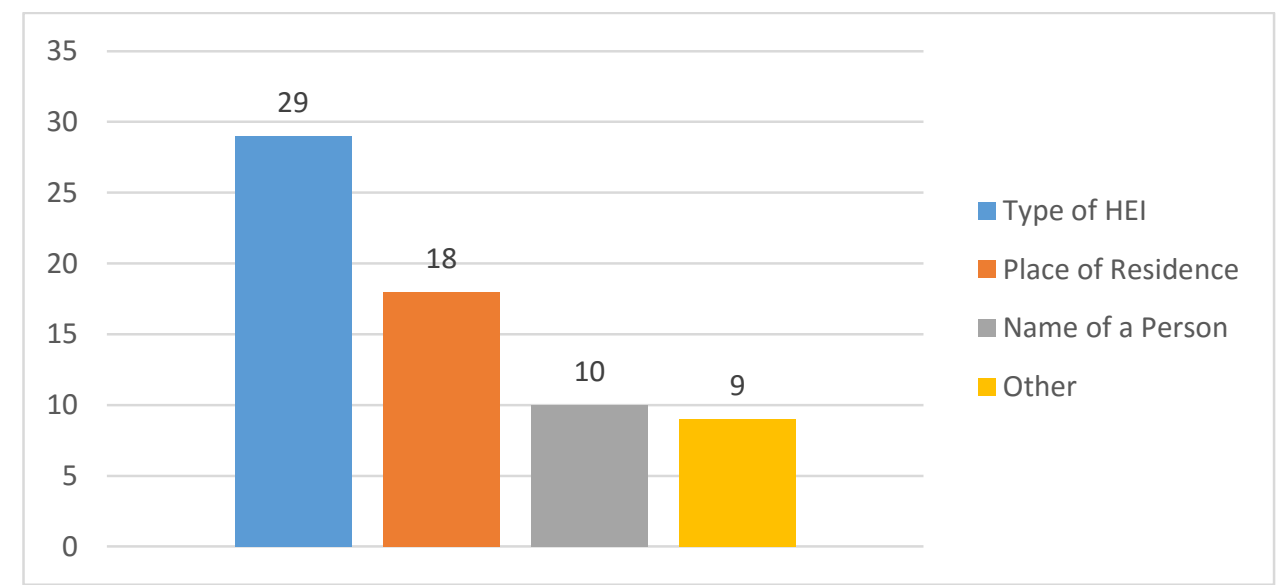

Figure 4. Distribution of the Most-frequent Tags in the Names of HEIs Founded in Turkey between 1980 and 1992 
The frequency rates presented in Figure 4 show that tags used in the names of HEIs founded in this period were grouped under three folders. The most frequent folder again belonged to 'Type of $\mathrm{HEI}^{\prime}$, which was dominated by the university tag. Only two HEIs carried the name Institute during this period (i.e., İzmir Institute of Technology and Gebze Institute of Technology). The second folder was 'Place of Residence', in which city names were in the majority and four tags referred to geographical areas (i.e., Akdeniz University, Trakya University, Kafkas University, and Harran University) and a neighborhood name (İhsan Doğramacı Bilkent University). The last frequent folder in this period was 'Name of a Person', which displayed variety in terms of those peoples' features. This group included five politicians (Celal Bayar, Adnan Menderes, Mustafa Kemal, Bülent Ecevit, Süleyman Demirel), three university founders (Muğla Sitkı Koçman, Abant İzzet Batsal, İhsan Doğramacı), a soldier (i.e., Gaziosmanpaşa University) and a public hero (i.e., Kahramanmaraş Sütçü İmam University). İhsan Doğramacı is the first non-profit foundation university in Turkey.

\section{3rd Period: 1993-2006}

The third period included 40 HEIs founded between 1993 and 2006. The distribution of frequent tags detected in this period is shown below.

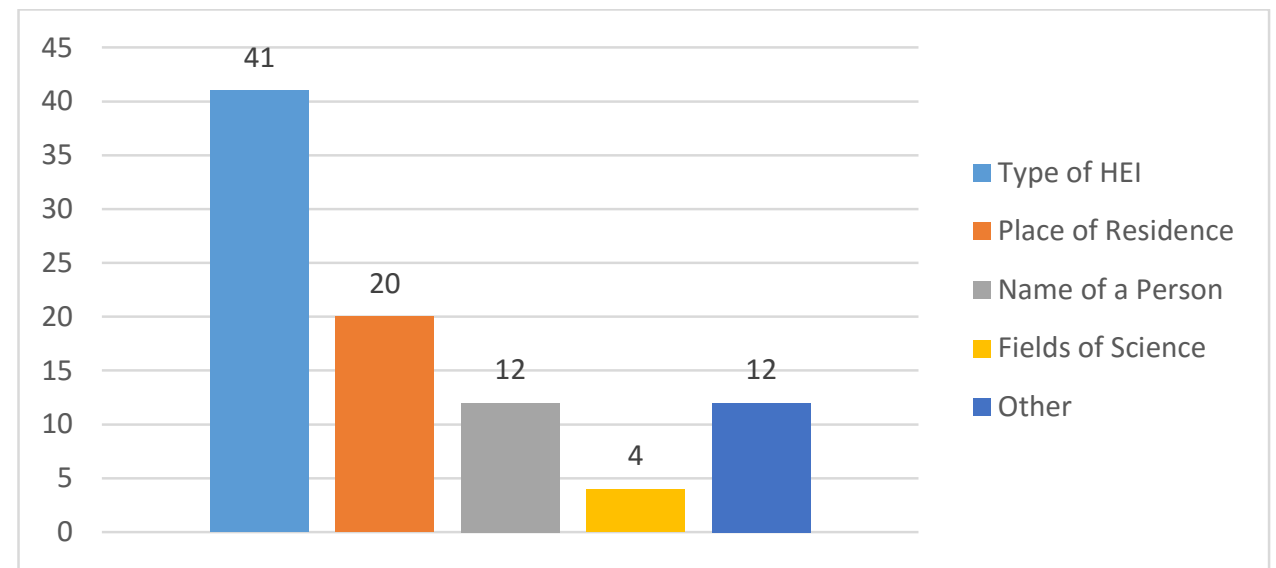

Figure 5. Distribution of the Most-frequent Tags in the Names of HEIs Founded in Turkey between 1993 and 2006

As shown in Figure 5, the tags used in the names of these institutions were grouped under four folders. As was the case in the previous periods, the most frequent folder was 'Type of HEI'; all of the tags in this folder were composed of the university tag, which shows that no other institution type was founded during this period. The next category was 'Place of Residence'; 15 of these places were city names (Eskişehir Osmangazi University, İstanbul Bilgi University, İzmir University of Economics, Ordu University, Adiyaman University, etc.). Compared with the previous periods, this finding may highlight a shift from more national themes to more localized motives. 'Name of a Person' was also a popular folder and name of founder was the dominant tag type in this category, representing 8 institutions (such as Ufuk, Okan, Yaşar, Koç University) attributable to the establishment of new nonprofit foundation universities. Finally, 4 tags from the 'Fields of Science' folder were associated with the names of HEIs founded in this period. These HEIs were Istanbul Commerce University, TOBB University of Economics and Technology, Izmir University of Economics.

4rd Period: After 2006

The final period defined in the history of HEIs in Turkey covers all HEIs founded after 2006. This period was marked with an increasing number of newly founded HEIs: 83. 


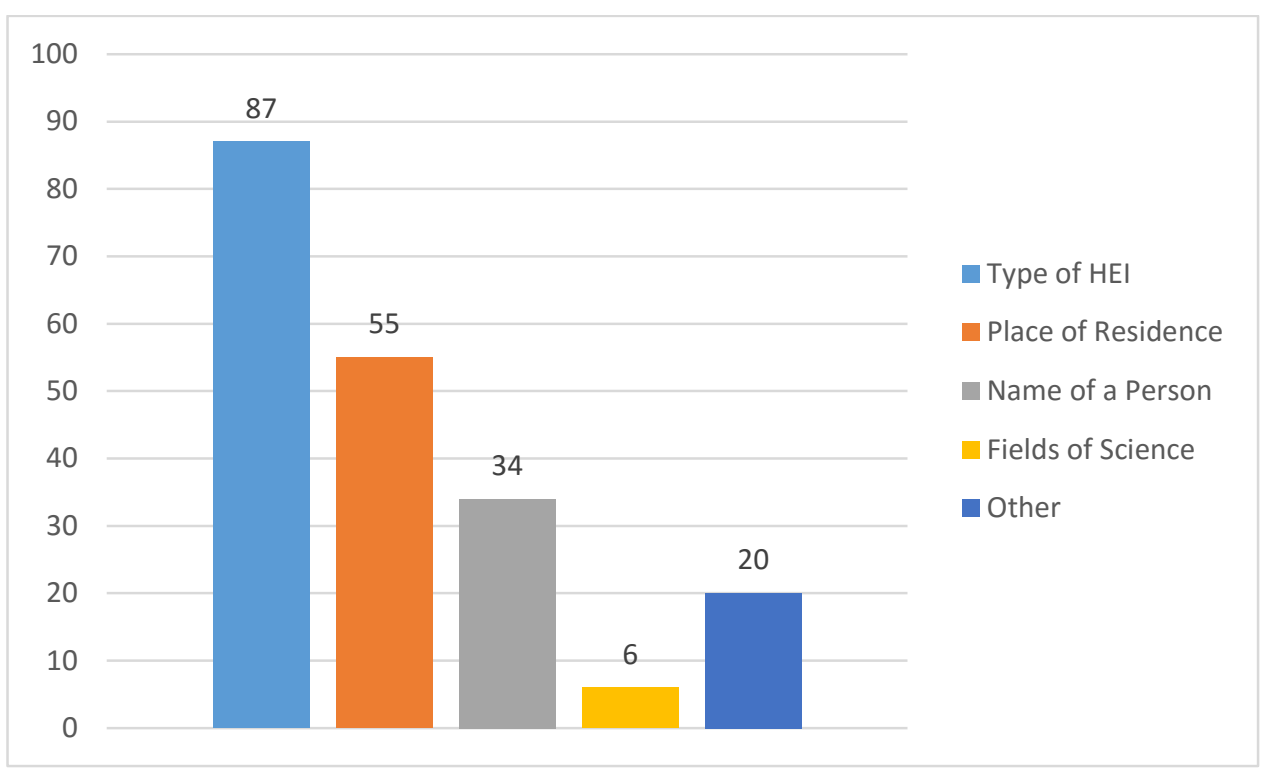

Figure 6. Distribution of the Most-frequent Tags in the Names of HEIs Founded in Turkey after 2006

As Figure 6 shows, the most frequent folder, 'Type of HEI', was used 87 times. The most frequent tag in this folder was university, which was involved in the names of all of the HEIs founded in this period. The other tags used once or twice were higher education, wakf or international as in Bezmi Alem Vakıf Üniversitesi. This was followed by the 'Place of Residence' folder. In this category, 45 tags were city names (i.e., Kilis, Bingöl, Mardin, Nevşehir, Osmaniye, Siirt) and 10 were neighborhood names. Universities were associated with the cities in which they were located. This popularity of place names might be attributable to the possibility that the new universities primarily aim to enroll students from their own cities. This raises the question of whether an HEI is local rather than regional, national or global even though the missions and functions of these universities are the same as the earlier-founded ones. 'Name of a Person' is the second most-frequent folder in which (especially) names of politicians (i.e., Necmettin Erbakan, Turgut Özal, Abdullah Gül University) and historically important people (i.e., Fatih Sultan Mehmet, Piri Reis, Süleyman Şah, Salahaddin Eyyubi, Kanuni, Biruni, and Şeyh Edebali) are seen. Here, it is primarily foundation universities that tend to prefer the names of their founders, such as Hasan Kalyoncu University and İstanbul Sabahattin Zaim University. The final folder was 'Fields of Science' with subfolders of 'Engineering', 'Social Sciences' and 'Agriculture' - for example, Bursa Technical University, Social Sciences University of Ankara, and Konya Food and Agriculture University. This finding shows that all of the HEIs founded in this period carry the university title. Diversification of the universities is planned by theme and field in these recently established universities.

\section{B) Time Intervals in the UK}

The HEIs in the UK were grouped under six historical periods ${ }^{3}$. The first period refers to the years before 1800 when the earliest HEIs in the UK were established. The second period is the $19^{\text {th }}$ century. The third period is between 1901 and 1944, in other worlds, it spans from the beginning of the century to World War II. The fourth period is between 1945 and 1965. The fifth period refers to the period between 1966 and 1991. Finally, the years after 1992 are the sixth period, during which new HEIs were established.

Two categories - 'Linguistic items' and 'Other' - were intentionally ignored in the analysis of the HEIs in the UK because the extensive usage of the former resulted from inherent features of the English language and the latter is merely a collection of tags that would be insignificant in number if presented separately.

\footnotetext{
${ }^{3}$ https://www.britishcouncil.in/sites/default/files/higher_education_system_of_uk.pdf
} 


\section{$1^{\text {st }}$ Period: Before 1800}

Eight HEIs were founded in the UK before the year 1800. Two folders (one of which is a subfolder) were mainly used to tag the names of HEIs in this period: 'Type of HEI' (8) and 'Place of Residence' (7) (Figure 7). All of the HEIs covered in the 'Type of HEI' folder were tagged as university. The tag chosen in the 'Place of Residence' folder was usually city name (6 out of 8 ), for example, University of Oxford and University of Cambridge. The naming of the HEIs during this time period was probably inspired by the HEI's actual location.

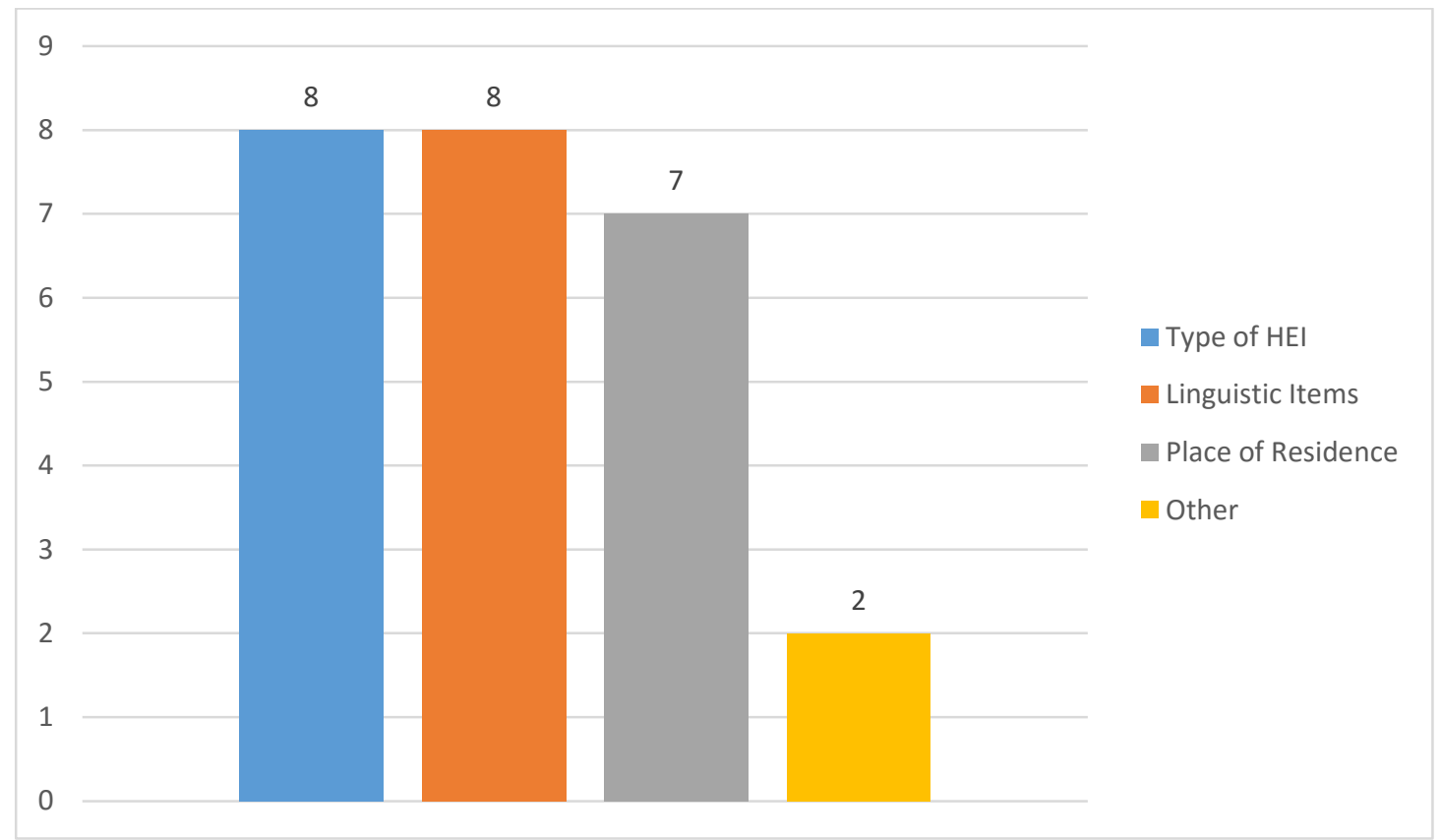

Figure 7. Distribution of the Most-frequent Tags in the Names of HEIs Founded in the UK before 1800

$2^{\text {nd }}$ Period: 19th Century

Forty-six HEIs were established in the UK between 1801 and 1900. As indicated in Figure 8, the main folders or subfolders used to tag the names of these HEIs were 'Type of HEI' (44), 'Place of Residence' (38) and 'Fields of Science' (21).

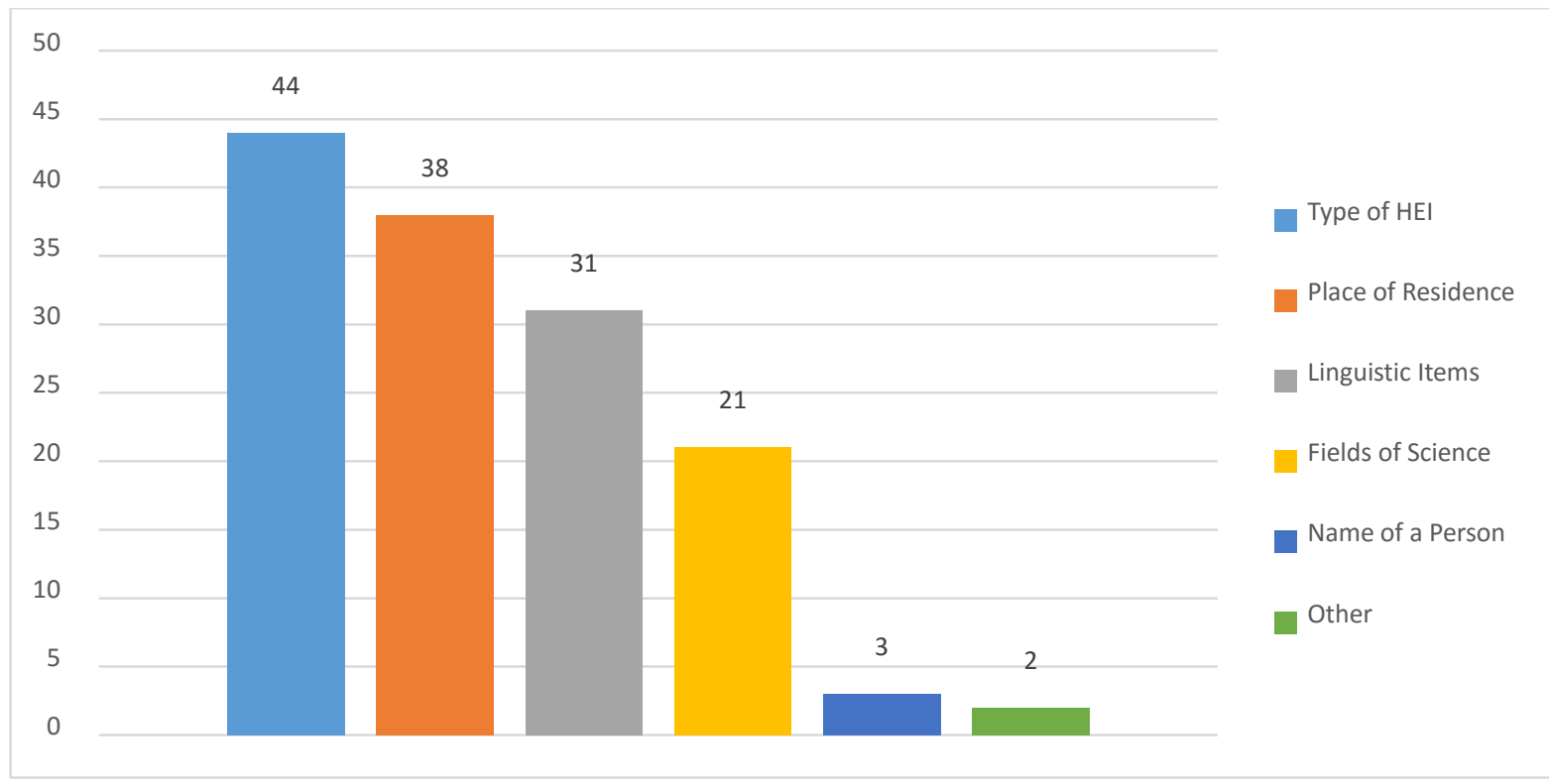

Figure 8. Distribution of the Most-frequent Tags in the Names of HEIs Founded in the UK between 1801 and 1900 
The tags university (i.e., Queen's University Belfast) and college (i.e., King's College London) were the most frequently used in the 'Type of HEI' folder. Other tags included school, royal (as in Royal College of Music) and academy (as in London Academy of Music and Dramatic Art). The city name (14) and capital name (12) tags were the majority in the 'Place of Residence' subfolder (i.e., University College London and Glasgow School of Art). A notable number of tags (13) in the 'Fine Arts' (i.e., Guildhall School of Music and Drama) subfolder in the 'Fields of Science' folder were also used. 'Medical Sciences' (i.e., London School of Hygiene and Tropical Medicine) and 'Social Sciences' (i.e., London School of Economics and Political Science) subfolders were also used, but not in remarkably large amounts.

As seen in the data, there was an increase in the variety of the words used in the names of HEIs during this period compared to the first period. First, and most importantly, the variation in the 'Type of HEI' folder shows that the organization of HEIs developed in time and HEIs with different structures or organizations took various names such as college, academy or university. As opposed to the dominance of the tag city name in the first period, there was almost the same number of capital name tags during this period. This can be interpreted as a sign of London becoming an educational center during the $19^{\text {th }}$ century. For the first time, 'Fields of Science' words started to be used in the names of HEIs in the UK. This might be assumed to show the HEIs' tendency to specialize in certain areas (social sciences, fine arts, medical sciences), which can be evaluated as a result of industrialization.

\section{3 ${ }^{\text {rd }}$ Period: Before World War II}

Thirty-one HEIs were established during this period. The most frequently used folders or subfolders were 'Type of HEI' with 39 usages, 'Fields of Science' with 19 usages, 'Place of Residence' with 16 usages, and 'Name of a Person' with eight usages.

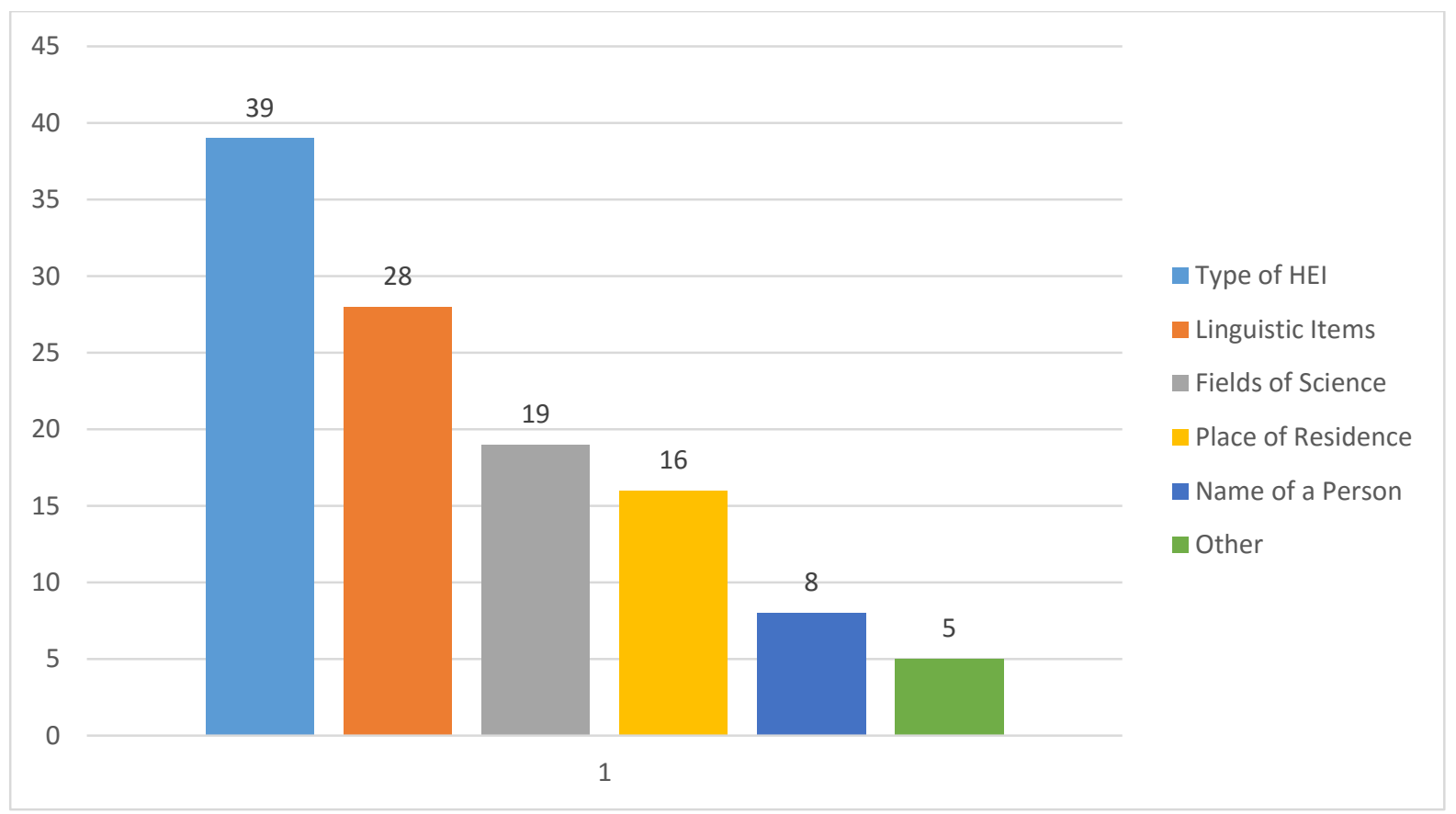

Figure 9. Distribution of the Most-frequent Tags in the Names of HEIs Founded in the UK before WWII (1901-1944) 
University, college and school, as in University of Southampton, Chelsea College of Arts, and London School of Theology, respectively, were the prominent tags in the 'Type of HEI' folder. Other tags included were institute, royal and academy. The folder 'Fields of Science' featured the subfolders 'Fine Arts' (4) (i.e., Edinburgh College of Art), 'Social Sciences' (3) (i.e., College of Estate Management), and 'Medical Sciences' (3) (i.e., Imperial College of Science, Technology and Medicine) as the top three tags. The most frequently used tags in 'Place of Residence' subfolder were city name (7) and capital name (7), as seen in Goldsmiths University of London and Edinburgh College of Art. Finally, founder tag was the most prominent tag in the 'Name of a Person' folder (i.e., Harper Adams University).

The distribution of the tags under the folder 'Type of HEI' in the $3^{\text {rd }}$ period resembled those of the $2^{\text {nd }}$ period. However, the number of HEIs tagged as 'Fields of Science' were more than 'Place of Residence' between 1901 and 1944. This may be interpreted as the result of more emphasis on specialization in certain areas and less emphasis on local values. In contrast to the first two periods mentioned, the names of HEI founders or benefactors were chosen as HEI names in this period, which may be an indication of the beginnings of private initiatives in the HEI sector.

$4^{\text {th }}$ Period: $1945-1965$

Thirty-seven HEIs were established during this period.

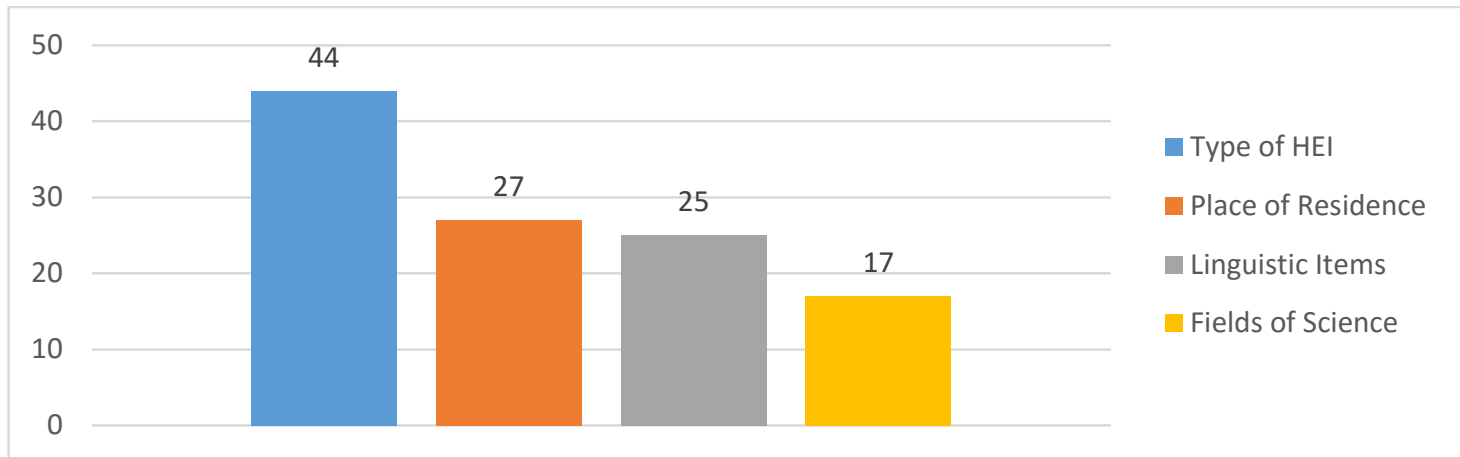

Figure 10. Distribution of the Most-frequent Tags in the Names of HEIs Founded in the UK between 1945 and 1965

The most prominent tags used in this period belonged to the folder 'Type of HEI' (44). The most frequent tag was college (11), followed by university (8) (as in Hartpury College and University of Exeter). Next came the subfolder 'Place of Residence' (27). The most commonly used tags in this folder were city name, county/parish name (i.e., University of Essex), village/town/riding name (i.e., Farnborough College of Technology), region name (i.e., North Highland College UHI) and capital name, with city name being used 15 times and the others being used less than five times. Seventeen words were tagged in the 'Fields of Science' folder and the most frequently used subfolders were 'Social Sciences' (5) and 'Fine Arts' (5), as in London School of Theology.

One interesting finding in this period is the popularity of the tag college. This may be interpreted as an organizational shift from university structure to college structure, which usually refers to a smaller type of institution specializing in certain fields. This assumption can also be supported by the fact that many HEIs established during this period were named after places smaller than cities, such as boroughs, parishes, villages or other similarly sized places. Both findings imply that there was a further localization of education in this period.

\section{$5^{\text {th }}$ Period: After 1966}

Forty-six HEIs were founded during the fifth period. Figure 11 shows that tags in 'Type of HEI', 'Place of Residence' and 'Fields of Science' folders or subfolders were used 56, 29 and 21 times, respectively. 'Name of a Person' was another folder used, though with less frequency. 


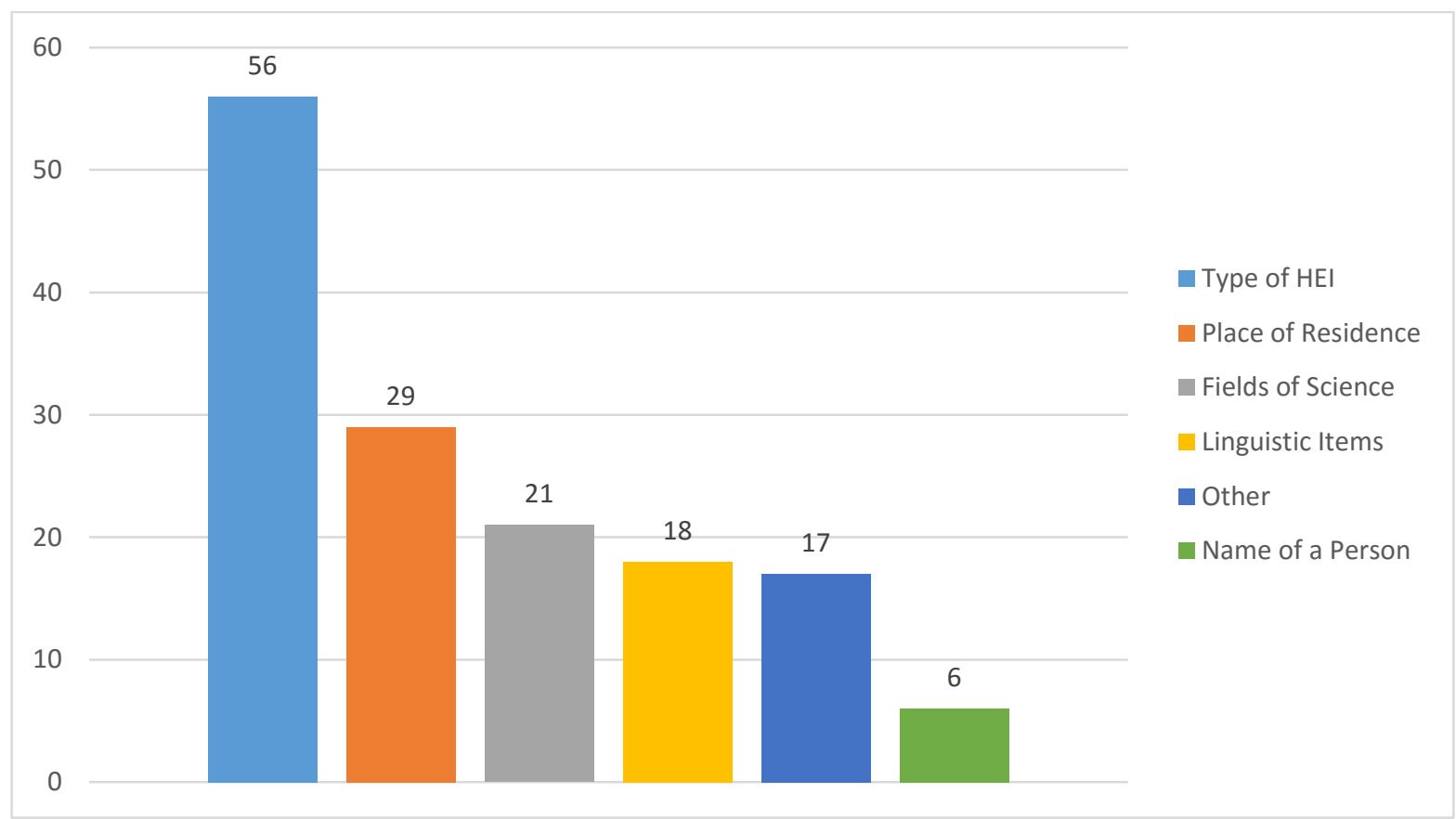

Figure 11. Distribution of the Most-frequent Tags in the Names of HEIs Founded in the UK between 1966 and 1991

The most frequently used tags in the 'Type of HEI' folder were college (14) and university (11), as in Newcastle College and University of Salford. The tag national was first used during this period (i.e., National Film and Television School). Next, we see the 'Place of Residence' subfolder with the leading tags of city name (8), capital name (7), village/town/riding name (4, i.e., University of Buckingham), and neighborhood name (2, i.e., Greenwich School of Management). Another frequently used folder was 'Fields of Science', for which the most popular tags were the 'Fine Arts' (10) and 'Social Sciences' (4) subfolders, as in Royal Northern College of Music and European Business School London. The tags used in the 'Name of a Person' folder were inventor, businessman (i.e., Heriot-Watt University), founder and religious figure (i.e., Saint Mary's University College), all of which were used once or twice.

The dominance of the tag college over university continued in the fifth period. Also resembling the previous period, the tags in the 'Place of Residence' subfolder included the names of small places such as towns and even neighborhoods. One striking difference was the focus on fine arts, as seen in numbers above.

6th Period: New Universities (After 1992)

One hundred and twenty-three new HEIs were established in the sixth period. As shown in Figure 12, the most frequent tags used in this period were nested in the following folders or subfolders: 'Type of HEI' (139), 'Place of Residence' (98) and 'Fields of Science' (38). 'Geographical Area', 'Various Concepts' and 'Name of a Person' folders were also used for tagging, albeit not with remarkable frequency. 


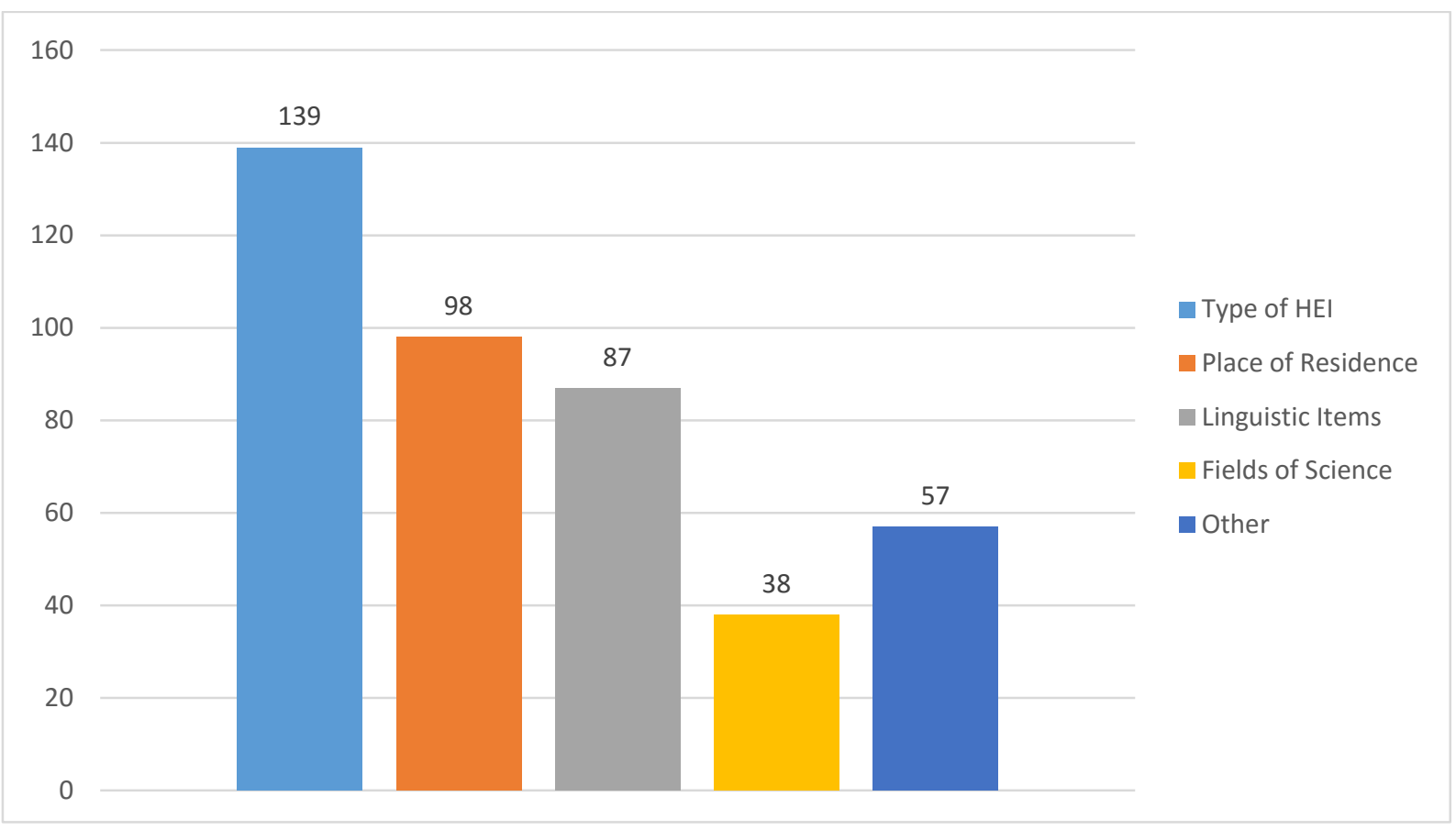

Figure 12. Distribution of the Most-frequent Tags in the Names of HEIs Founded in the UK between 1992 and 2015

The 'Type of HEI' folder included a variety of tags, with university (79), college (22), school (13) and institute (7) being the most frequently used. Most of the HEI names tagged in the 'Place of Residence' subfolder carried the city name, capital name (i.e., London South Bank University), village/town/riding name, county/parish name (i.e., University of Central Lancashire) and country name (University of the West of Scotland) tags. In the 'Fields of Science' folder, the prominent tags were found in the 'Fine Arts' subfolder, as in Liverpool Institute of Performing Arts and Royal Drawing School, and in the 'Social Sciences' subfolder, as in City Law School.

During the period of new universities, there has been a shift towards the use of the university tag. However, a wide range of tags was frequently used in the 'Type of HEI' folder. The variation in 'Place of residence' continued. The tag 'country name' was first seen in this period, which could show that HEIs that aim to embrace larger areas came forward together with smaller and localized HEIs. The diversity of the tags used in this period can be interpreted as a sign of the globalization of HEIs in the UK in recent times, attempting to meet different expectations of the new world. 


\section{Conclusion}

This paper focused on a topic involving an under-researched aspect of higher education. It investigated the names of selected HEIs in Turkey and the UK in certain categories collected by the WHEINM project at the Social Sciences University of Ankara. The motivation for the project was to categorize the names of HEIs into frequent or common categories so that it would be possible to compare and contrast whether those names reflected any significant similarities and/or differences related to cultural and geographical values. In this study, we also aimed to determine the extent to which the chronological appearance of selected HEIs affected their naming processes.

As stated above, this paper is derived from the WHEINM project and aimed to contribute to national and international higher education research. In this sense, our main findings could inspire further studies on this topic. With full awareness of the various types of higher education systems in terms of establishment, governance and funding, this article's main research question is to examine if there are any similarities or differences between the name categories of the Turkish and British HEIs. To answer this main question we retrieved data for the most frequently used name categories in both countries. In our analysis, we concluded that the most frequent categories in which Turkish HEIs appeared were 'Place of Residence', 'Name of a Person', and 'Fields of Science', whereas the names of UK HEIs also were categorized into 'Geographic Areas', 'Various Concepts', and 'Linguistic Items'. It is possible to suggest that because of the UK's history and culture, the HEIs in that country are more diverse and therefore, there is a wide range of tags, particularly in the Type of HEI folder. The HEIs in Turkey are less diverse, probably because of the clear definition of the HEI law, which frames the establishment of HEIs.

By searching the data according to the foundation years of the HEIs in each country, we found that in Turkey, the name categories evolved chronologically. The primary tendency to use geographical terms (such as regional or mountain names) is replaced by city names, especially among recently founded HEIs. Additionally, a change was also detected in the names of persons. Whereas the initially founded HEIs carry the name of politicians and historically important figures, more recent HEIs were named after their founders or benefactors. It should also be stated that there is a significant increase in the number of recently established non-profit foundation HEIs. A time-based evolution was also observed in UK HEI names. The variety of HEI types increased over time. Whereas early instances of HEIs were merely named "university", names such as "college" or "school" appeared in later periods. This indicates a change in the structure of HEIs, probably from more central and comprehensive to more local and specialized. Having been named after the founder of the institution, the HEIs established around the 1900s can pinpoint the time during which private initiatives began in the HEI sector. Although names of large cities and the capital, London, were frequently used in the names of HEIs at the beginning of the period under study, names of smaller local areas were often chosen as HEI names starting from 1945. These three findings may indicate that with the rise of capitalization, the HEI sector became more specialized and diversified in terms of their functions and outcomes. 
Although the project team made a substantial effort to eliminate any limitations that could affect the academic reliability of the project, the study has some inevitable limitations. The primary limitation has emerged in relation to the difficulty of reaching the official web sources to collect data (name and basic information about the HEIs) for both countries. In other words, the websites of HEIs or even formal sources frequently were seen as lacking required information. Although the utmost importance was given to using either the countries' official resources (such as ministries) or international sources such as the OECD and UNESCO, other sources such as Wikipedia were used for cases in which official web sites failed to provide the necessary information. Thus, it is important to clearly state that we are cautious about the internal validity of the gathered data when we view internal validity as the answer to the question of 'How congruent are one's findings with reality?' as suggested by Merriam (1995). We are concerned about internal validity because part of the institutional data might be somewhat misleading because of the difficulty that we experienced in obtaining authentic sources of information. Additionally, we are aware of the major risk that various people might suggest results from the use of various categories in the labeling process. For instance, labeling a name such as Mevlana (under the main category of Famous People) is possible through the use of tags such as philosopher and religious figure. In this type of case, we relied on decisions derived from common discussions among our research team. However, we attempt to alleviate these concerns by assuming reality is not static; our purpose in this study is to develop an understanding of the general picture. To claim generalizable results, we strongly suggest re-checking and revising (if necessary) the elicited data for further studies. Another concern is the lack of similar projects on this topic to compare the structure, methodology and literature; however, this makes the project unique. Further research will certainly discover different aspects of naming strategies and their effects on HEIs for stakeholders such as parents, students, employers and other related bodies.

In conclusion, it can be argued that this research attempts to reflect commonalities of the HEIs in their name categories. Although the project is descriptive and data-driven, further qualitative research could provide insight into the impact of HEIs' names used for marketing and branding purposes to attract prospective students and their families. Furthermore, names may give clues about the systems and the HEIs with respect to their association with rural, regional, national or international places; people; and different thematic and scientific fields as part of their branding and marketing strategies. It was hypothesized that the results of this study would display country-specific details to be analyzed for certain indicators such as their geographical hinterland and cultural values, or even scientific improvements or political decisions that were influential at the time of their foundation.

\section{Acknowledgement}

We owe our special thanks both to the Unit of Scientific Research Projects of Social Sciences University of Ankara for funding the project titled World Higher Education Institutions Name Map, the data of which was utilized extensively for conducting this study, and to all members of the project team. 


\section{References}

Alessandri, S. (2001). Modeling corp identity: A concept explication and theoretical explanation. Corporate Communications: An International Journal, 6(4), 173-182.

Anderson, R. (2006). British Universities Past and Present. London: Continuum.

Barich, H., \& Kotler, P. (1991). A framework for marketing image management. Sloan Manage Rev, 32(2), 94-104.

British Council. (n.d.). Higher Education System of UK. Retrieved from https://www.britishcouncil.in/sites/default/files/higher_education_system_of_uk.pdf

Cortese, A. D. (2003). The critical role of higher education in creating a sustainable future. Planning for Higher Education, 31(3), 15-22.

Çetinsaya, G. (2014). Büyüme, Kalite, Uluslarasılaşma: Türkiye Yükseköğretimi için bir Yol Haritası. Retrieved from https://yolharitasi.yok.gov.tr/docs/YolHaritasi.pdf

Doğan, V. (2009). Brand name strategies at universities: Comparison of three distinct naming strategies. Journal of Management and Marketing Research, 14, 3-12

Europass. (n.d.). Description of Higher Education in England, Wales and Northern Ireland. Retrieved from http://www.ecctis.co.uk/europass/documents/ds_description.pdf

Günay, D., \& Günay, A. (2011). 1933'den günümüze Türk yükseköğretiminde niceliksel gelişmeler. Yükseköğretim ve Bilim Dergisi, 1(1), 1-22.

Hemsley-Brown, J., \& Goonawardana, S. (2007). Brand harmonisation in the international higher education market. Journal of Business Research, 60, 942-948.

Ivy, J. (2001). Higher education institution image: A correspondence analysis approach. International Journal of Educational Management, 15(6), 276-282.

Kennedy, S. (1977). Nurturing institutional image. European Journal of Marketing, 11(3), 120-164.

Landrum, R. E., Turrisi, R., \& Harless, C. (1998). University image: The benefits of assessment and modeling. Journal of Marketing for Higher Education, 9(1), 53-68.

Merriam, S. B. (1995). Theory to practice: What can you tell from $\mathrm{N}$ of 1?: Issues of validity and reliability in qualitative research. PAACE Journal of Lifelong Learning, 4, 51-60.

Mourad, M., Ennew, C., \& Kortam, W. (2011). Brand equity in higher education. Marketing Intelligence and Planning, 29(4), 403-420.

Neumark, V. (2012, April 3). What's in a Name? The Value of a Good University Brand. Retrieved from http://www.theguardian.com/higher-education-network/blog/2012/apr/03/brandinguniversities

Nguyen, N., \& LeBlanc, G. (2001). Image and reputation of higher education institutions in students' retention decision. International Journal of Educational Management, 15(6), 303-311.

OECD. (2007). Higher Education and Regions: Globally Competitive, Locally Engaged. Retrieved from http://www.oecd.org/edu/imhe/39378517.pdf

OECD. (n.d.). Revised Field of Science and Technology (fos) Classification in the Frascati Manual. Retrieved from http://www.oecd.org/science/inno/38235147.pdf

Peluso, A. M., \& Guido, G. (2012). Effects of geographical university names on users' perceptions. The Journal of Brand Management, 19(4), 344-357.

Pfoertsch, W., Linder, C., Beuk, F., Bartikowski, B., \& Luczak, C. A. (2007). B2B brand definitionunderstanding the role of brands in business and consumer market. Pforzheimer Forschungsberichte, 9, 1-13.

Slaughter, S., \& Leslie, L. L. (1997). Academic Capitalism: Politics, Policies, and the Entrepreneurial University. Baltimore: The Johns Hopkins University Press. 
Universities UK. (2014). Patterns and Trends in UK Higher Education. Retrieved from http://www.universitiesuk.ac.uk/highereducation/Documents/2014/PatternsAndTrendsInUKHig herEducation2014.pdf

Universities UK. (2015). Higher Education in Facts and Figures 2015. Retrieved from http://www.universitiesuk.ac.uk/highereducation/Documents/2015/higher-education-in-factsand-figures-2015.pdf

Van der Wende, M. (2009). European Responses to Global Competitiveness in Higher Education. Retrieved from ERIC databases (ED507065).

Van Riel, C. B., \& Balmer, J. M. (1997). Corporate identity: The concept, its measurement and management. European Journal of Marketing, 31(5/6), 340-355.

Waeraas, A., \& Solbakk, M. N. (2009). Defining the essence of a university: Lessons from higher education branding. Higher Education, 57(4), 449-462.

Webster, F. E., \& Keller, K. L. (2004). A roadmap for branding in industrial markets. The Journal of Brand Management, 11(5), 388-402.

White, J. (1997). Philosophy and the aims of higher education. Studies in Higher Education, 22(1), 7-17.

YÖK. (n.d.). Yükseköğretim İstatistikleri. Retrieved October 5, 2015, from https://istatistik.yok.gov.tr

Zaghloul, A. A., Hayajneh, Y. A., \& Almarzouki, A. (2010). Factor analysis for an institutional image instrument. International Review on Public and Nonprofit Marketing, 7(2), 157-166. 
Appendix 1. Folder Names and Tags

\begin{tabular}{|c|c|c|}
\hline Folder & Subfolder & Label \\
\hline \begin{tabular}{|l|} 
DİL BILGİSEL / \\
FONKSIYONEL \\
KELIMELER \\
(Linguistic Items) \\
\end{tabular} & $\begin{array}{l}\text { Dil Bilgisel / Fonksiyonel Kelimeler } \\
\text { (Linguistic Items) }\end{array}$ & \\
\hline \multirow[t]{12}{*}{$\begin{array}{l}\text { KAVRAM / KONSEPT } \\
\text { (Concept) }\end{array}$} & ÇEŞITLİ KAVRAMLAR (Various Concepts) & Askeri Kavram \\
\hline & ÇEŞITLİ KAVRAMLAR (Various Concepts) & Cinsiyet \\
\hline & ÇEŞITLİ KAVRAMLAR (Various Concepts) & Diğer kavramlar \\
\hline & ÇEŞITLİ KAVRAMLAR (Various Concepts) & Geometrik Şekil \\
\hline & ÇEŞITLİ KAVRAMLAR (Various Concepts) & Gida \\
\hline & ÇEŞITLİ KAVRAMLAR (Various Concepts) & İklim \\
\hline & ÇEŞITLİ KAVRAMLAR (Various Concepts) & Kariyer \\
\hline & ÇEŞITLİ KAVRAMLAR (Various Concepts) & Kültür \\
\hline & ÇEŞITLİ KAVRAMLAR (Various Concepts) & Medeniyet \\
\hline & ÇEŞITLİ KAVRAMLAR (Various Concepts) & Renk \\
\hline & ÇEŞITLİ KAVRAMLAR (Various Concepts) & Sifat \\
\hline & ÇEŞITLİ KAVRAMLAR (Various Concepts) & Takma Ad / Ünvan \\
\hline \multirow[t]{8}{*}{$\begin{array}{l}\text { KAVRAM / KONSEPT } \\
\text { (Concept) }\end{array}$} & DINI KAVRAM (Religious Concept) & Budizm \\
\hline & DİNİ KAVRAM (Religious Concept) & Hristiyanlık \\
\hline & DİNİ KAVRAM (Religious Concept) & İslam \\
\hline & DİNİ KAVRAM (Religious Concept) & Katolik \\
\hline & DİNİ KAVRAM (Religious Concept) & Kutsal kitap \\
\hline & DİNİ KAVRAM (Religious Concept) & Ortodoks \\
\hline & DINII KAVRAM (Religious Concept) & Protestan \\
\hline & DİNI KAVRAM (Religious Concept) & Yahudilik \\
\hline \multirow[t]{2}{*}{$\begin{array}{l}\text { KISALTMA } \\
\text { (Abbreviation) }\end{array}$} & & Kurum \\
\hline & & Şahıs \\
\hline \multirow[t]{3}{*}{ KIMLIK (Identity) } & & Dini \\
\hline & & Etnisite / Irk / Milliyet \\
\hline & & Kabilesel \\
\hline \multirow[t]{21}{*}{ KONUM (Location) } & COĞRAFİ YAPI (Geographical Structure) & Ada \\
\hline & COĞRAFİ YAPI (Geographical Structure) & Boğaz/Geçit \\
\hline & COĞRAFİ YAPI (Geographical Structure) & Burun \\
\hline & COĞRAFİ YAPI (Geographical Structure) & Dağ \\
\hline & COĞRAFİ YAPI (Geographical Structure) & Delta \\
\hline & COĞRAFI YAPI (Geographical Structure) & Deniz \\
\hline & COĞRAFİ YAPI (Geographical Structure) & Göl \\
\hline & COĞRAFİ YAPI (Geographical Structure) & Havza \\
\hline & COĞRAFİ YAPI (Geographical Structure) & Kırsal \\
\hline & COĞRAFİ YAPI (Geographical Structure) & Kita \\
\hline & COĞRAFİ YAPI (Geographical Structure) & Kiyı/Sahil \\
\hline & COĞRAFİ YAPI (Geographical Structure) & Körfez \\
\hline & COĞRAFİ YAPI (Geographical Structure) & Mağara \\
\hline & COĞRAFİ YAPI (Geographical Structure) & Nehir \\
\hline & COĞRAFİ YAPI (Geographical Structure) & Okyanus \\
\hline & COĞRAFİ YAPI (Geographical Structure) & Ova \\
\hline & COĞRAFİ YAPI (Geographical Structure) & Plato \\
\hline & COĞRAFİ YAPI (Geographical Structure) & Şekil \\
\hline & COĞRAFİ YAPI (Geographical Structure) & Şelale \\
\hline & COĞRAFİ YAPI (Geographical Structure) & Tepe \\
\hline & COĞRAFİ YAPI (Geographical Structure) & Vadi \\
\hline
\end{tabular}




\begin{tabular}{|c|c|c|}
\hline & COĞRAFİ YAPI (Geographical Structure) & Yarımada \\
\hline & COĞRAFİ YAPI (Geographical Structure) & Yildiz \\
\hline & COĞRAFİ YAPI (Geographical Structure) & Yol \\
\hline & COĞRAFİ YAPI (Geographical Structure) & Yön \\
\hline \multirow[t]{11}{*}{ KONUM (Location) } & MEKAN / YAPI (Building/Structure) & Hastane \\
\hline & MEKAN / YAPI (Building/Structure) & Havaalan 1 \\
\hline & MEKAN / YAPI (Building/Structure) & İbadethane / Tapinak \\
\hline & MEKAN / YAPI (Building/Structure) & Kale \\
\hline & MEKAN / YAPI (Building/Structure) & Kampüs \\
\hline & MEKAN / YAPI (Building/Structure) & Kaplica /Spa \\
\hline & MEKAN / YAPI (Building/Structure) & Köprü \\
\hline & MEKAN / YAPI (Building/Structure) & Mezarlık \\
\hline & MEKAN / YAPI (Building/Structure) & Müze \\
\hline & MEKAN / YAPI (Building/Structure) & Park/ Milli Park \\
\hline & MEKAN / YAPI (Building/Structure) & Tarihi Yapı \\
\hline \multirow[t]{10}{*}{ KONUM (Location) } & YERLEŞIM BİRİMİ (Place of Residence) & Adres / Konum \\
\hline & YERLEŞIM BİRİMİ (Place of Residence) & Başkent Ad1 \\
\hline & YERLEŞIM BİRİMİ (Place of Residence) & Bölge Ad1 \\
\hline & YERLEŞIM BİRİMİ (Place of Residence) & Eyalet Ad1 \\
\hline & YERLEŞIM BİRİMİ (Place of Residence) & İdari Bölge Ad1 \\
\hline & YERLEŞIM BİRİMİ (Place of Residence) & Köy/Kasaba/İlçe Adı \\
\hline & YERLEŞIM BİRİMİ (Place of Residence) & Özerk/Otonom \\
\hline & YERLEŞIM BİRİMİ (Place of Residence) & Şehir Ad1 \\
\hline & YERLEŞIM BİRİMİ (Place of Residence) & Semt / Mahalle Ad1 \\
\hline & YERLEŞIM BíRİMİ (Place of Residence) & Ülke Adı \\
\hline \multirow[t]{28}{*}{$\begin{array}{l}\text { OKUL TÜRÜ / } \\
\text { ÖZELLIĞİ (School } \\
\text { Type / Feature) }\end{array}$} & & Açık / Uzaktan \\
\hline & & Akademi \\
\hline & & Araştırma \\
\hline & & Bakanlık/Resmi Birim \\
\hline & & Belediye \\
\hline & & Bilim/Bilimsel \\
\hline & & Birleşik / Bütünleşik / Bütünleyici \\
\hline & & Bölgesel \\
\hline & & Cumhuriyet \\
\hline & & Devlet (State) / Hükümet \\
\hline & & Dini okul/Papaz/Haham Okulu \\
\hline & & Eğitim Merkezi \\
\hline & & Enstitü \\
\hline & & Fakülte \\
\hline & & Federal \\
\hline & & Kolej \\
\hline & & Konservatuar \\
\hline & & Kraliyet \\
\hline & & Küresel \\
\hline & & Lisansüstü \\
\hline & & Merkez \\
\hline & & Meslek Yüksek Okulu \\
\hline & & Okul \\
\hline & & Şehir \\
\hline & & Topluluk Koleji \\
\hline & & Ulusal \\
\hline & & Uluslararası \\
\hline & & Üniversite \\
\hline
\end{tabular}




\begin{tabular}{|c|c|c|}
\hline & & Uygulamalı Bilimler \\
\hline & & Vakıf/Özel \\
\hline & & Yetişkin Eğitimi \\
\hline & & Yüksek Öğretim \\
\hline & & Yüksek Okul \\
\hline \multirow[t]{2}{*}{$\begin{array}{l}\text { SAYI / TARİH } \\
\text { (Number/Date) }\end{array}$} & & Önemli Tarih \\
\hline & & Say1 \\
\hline \multirow[t]{5}{*}{ TOPLULUK (Groups) } & & Federasyon \\
\hline & & Polis Federasyonu \\
\hline & & Şirket \\
\hline & & Tarihi Topluluk \\
\hline & & Topluluk/ Cemiyet / Dernek \\
\hline \multirow[t]{30}{*}{$\begin{array}{l}\text { UZMANLIK ALANI } \\
\text { (Fields of Science) }\end{array}$} & & $\begin{array}{l}\text { Disiplinlerarası Çalışmalar } \\
\text { (Interdisciplinary Studies) }\end{array}$ \\
\hline & BEŞERİ BİLIMLER (Humanities) & 1.Tarih ve Arkeoloji \\
\hline & BEŞERİ BILLIMLER (Humanities) & 2.Dil ve Edebiyat \\
\hline & BEŞERİ BILIIMLER (Humanities) & 3.Felsefe, Ahlakbilim ve Din \\
\hline & BEŞERİ BILIIMLER (Humanities) & 5.Diğer Beşeri Bilimler \\
\hline & BEŞERİ BILIIMLER (Humanities) & Beşeri Bilimler \\
\hline & $\begin{array}{l}\text { DOĞA BİLIMLERİ / TEMEL BİLIMLER } \\
\text { (Natural Sciences) }\end{array}$ & 1.Matematik \\
\hline & $\begin{array}{l}\text { DOĞA BİLIMMLERİ / TEMEL BİLIMMLER } \\
\text { (Natural Sciences) }\end{array}$ & 2.Bilgisayar ve Bilişim Bilimleri \\
\hline & $\begin{array}{l}\text { DOĞA BİLIMLERİ / TEMEL BİLIMLER } \\
\text { (Natural Sciences) }\end{array}$ & 3.Fen Bilimleri \\
\hline & $\begin{array}{l}\text { DOĞA BILLIMLERİ / TEMEL BİLIMLER } \\
\text { (Natural Sciences) }\end{array}$ & 4.Kimya Bilimi \\
\hline & $\begin{array}{l}\text { DOĞA BILLIMLERİ / TEMEL BILIIMLER } \\
\text { (Natural Sciences) }\end{array}$ & 5.Yeryüzü ve Çevre Bilimleri \\
\hline & $\begin{array}{l}\text { DOĞA BİLIMLERİ / TEMEL BİLIMLER } \\
\text { (Natural Sciences) }\end{array}$ & 6.Biyoloji Bilimi \\
\hline & $\begin{array}{l}\text { DOĞA BILLIMLERİ / TEMEL BILIIMLER } \\
\text { (Natural Sciences) }\end{array}$ & Doğa Bilimleri \\
\hline & GÜZEL SANATLAR (Fine Arts) & Dans \\
\hline & GÜZEL SANATLAR (Fine Arts) & Görsel \\
\hline & GÜZEL SANATLAR (Fine Arts) & Güzel Sanatlar / Tasarım \\
\hline & GÜZEL SANATLAR (Fine Arts) & Moda \\
\hline & GÜZEL SANATLAR (Fine Arts) & Müzik / Müzik ve Pedagoji \\
\hline & GÜZEL SANATLAR (Fine Arts) & Tiyatro \\
\hline & HIIZMET (Services) & Aşçılık \\
\hline & HIIZMET (Services) & Cenaze Hizmetleri \\
\hline & HIIZMET (Services) & Güvenlik/savunma \\
\hline & HIIZMET (Services) & Güzellik \\
\hline & HIZMET (Services) & Hizmet \\
\hline & HIZZMET (Services) & Turizm \\
\hline & $\begin{array}{l}\text { MÜHENDİSLIK VE TEKNOLOJİ } \\
\text { (Engineering and Technology) }\end{array}$ & 1.İnşaat Mühendisliği \\
\hline & $\begin{array}{l}\text { MÜHENDİSLIK VE TEKNOLOJİ } \\
\text { (Engineering and Technology) }\end{array}$ & 10.Nano teknoloji \\
\hline & $\begin{array}{l}\text { MÜHENDİSLIK VE TEKNOLOJİ } \\
\text { (Engineering and Technology) }\end{array}$ & 11.Diğer Mühendislik ve Teknolojileri \\
\hline & $\begin{array}{l}\text { MÜHENDİSLIK VE TEKNOLOJİ } \\
\text { (Engineering and Technology) }\end{array}$ & $\begin{array}{l}\text { 2.Elektrik Mühendisliği, Elektronik } \\
\text { Müh., Enformatik Müh. }\end{array}$ \\
\hline & MÜHENDİSLIK VE TEKNOLOJİ & 3.Makine Mühendisliği \\
\hline
\end{tabular}




\begin{tabular}{|c|c|c|}
\hline & (Engineering and Technology) & \\
\hline & $\begin{array}{l}\text { MÜHENDİSLIK VE TEKNOLOJİ } \\
\text { (Engineering and Technology) }\end{array}$ & 4.Kimya Mühendisliği \\
\hline & $\begin{array}{l}\text { MÜHENDİSLIK VE TEKNOLOJİ } \\
\text { (Engineering and Technology) }\end{array}$ & 5.Malzeme Mühendisliği \\
\hline & $\begin{array}{l}\text { MÜHENDİSLIK VE TEKNOLOJİ } \\
\text { (Engineering and Technology) }\end{array}$ & 6.Medikal Mühendisliği \\
\hline & $\begin{array}{l}\text { MÜHENDISLIIK VE TEKNOLOJİ } \\
\text { (Engineering and Technology) }\end{array}$ & 7.Çevre Mühendisliği \\
\hline & $\begin{array}{l}\text { MÜHENDİSLIK VE TEKNOLOJİ } \\
\text { (Engineering and Technology) }\end{array}$ & 8.Çevresel Biyoteknoloji \\
\hline & $\begin{array}{l}\text { MÜHENDİSLIK VE TEKNOLOJİ } \\
\text { (Engineering and Technology) }\end{array}$ & 9.Endüstriyel Biyoteknoloji \\
\hline & $\begin{array}{l}\text { MÜHENDİSLIK VE TEKNOLOJİ } \\
\text { (Engineering and Technology) }\end{array}$ & Bilim \\
\hline & $\begin{array}{l}\text { MÜHENDİSLIK VE TEKNOLOJİ } \\
\text { (Engineering and Technology) }\end{array}$ & Hava / Havacılık \\
\hline & $\begin{array}{l}\text { MÜHENDİSLIKK VE TEKNOLOJİ } \\
\text { (Engineering and Technology) }\end{array}$ & Teknoloji/Teknolojik/Teknik \\
\hline & SOSYAL BILIIMLER (Social Sciences) & 1.Psikoloji \\
\hline & SOSYAL BILIIMLER (Social Sciences) & 2.íktisat ve İşletme \\
\hline & SOSYAL BİLIMLER (Social Sciences) & 3.Ĕ̆itim Bilimleri \\
\hline & SOSYAL BİLIMLER (Social Sciences) & 4.Sosyoloji \\
\hline & SOSYAL BİLIMLER (Social Sciences) & 5.Hukuk \\
\hline & SOSYAL BILIIMLER (Social Sciences) & 6.Siyaset Bilimi \\
\hline & SOSYAL BILIMLER (Social Sciences) & 7.Sosyal ve ekonomik Coğrafya \\
\hline & SOSYAL BİLIMLER (Social Sciences) & 8.Medya ve İletişim \\
\hline & SOSYAL BİLIMLER (Social Sciences) & 9.Diğer Sosyal Bilimler \\
\hline & SOSYAL BİLIMLER (Social Sciences) & Ĕgitim \\
\hline & SOSYAL BİLIMLER (Social Sciences) & Sosyal Bilimler \\
\hline & SPOR (Sports) & Spor \\
\hline & $\begin{array}{l}\text { TIP VE SAĞLIK BİLIMMLERİ } \\
\text { (Medical and Health Sciences) }\end{array}$ & 1.Temel Tip \\
\hline & $\begin{array}{l}\text { TIP VE SAĞLIK BİLIMLERI } \\
\text { (Medical and Health Sciences) }\end{array}$ & 2.Klinik Tip \\
\hline & $\begin{array}{l}\text { TIP VE SAĞLIK BİLIMMLERİ } \\
\text { (Medical and Health Sciences) }\end{array}$ & 3.Sağlık Bilimleri \\
\hline & $\begin{array}{l}\text { TIP VE SAĞLIK BİLiMLERİ } \\
\text { (Medical and Health Sciences) }\end{array}$ & 4.Medikal Biyoteknoloji \\
\hline & $\begin{array}{l}\text { TIP VE SAĞLIK BİLIMLERİ } \\
\text { (Medical and Health Sciences) }\end{array}$ & 5.Diğer Sağlık Bilimleri \\
\hline & $\begin{array}{l}\text { TIP VE SAĞLIK BİLIMMLERİ } \\
\text { (Medical and Health Sciences) }\end{array}$ & Tıp / Tıp Bilimleri \\
\hline & ZİRAİ BİLİMLER (Agricultural Sciences) & 1.Ziraat, Ormancilık, Su ürünleri \\
\hline & ZIRAİ BILLIMLER (Agricultural Sciences) & 2.Hayvan ve Süt ürünleri Bilimi \\
\hline & ZIRAİ BİLIMLER (Agricultural Sciences) & 3.Veterinerlik Bilimi \\
\hline & ZIRAİ BILIIMLER (Agricultural Sciences) & 4.Zirai Biyoteknoloji \\
\hline & ZIRAİ BİLIMLER (Agricultural Sciences) & 5.Diğer Zirai Bilimler \\
\hline $\begin{array}{l}\text { ÜNLÜ Kİşi / Li்ER } \\
\text { (Famous Person/ } \\
\text { Leader) }\end{array}$ & & $\begin{array}{l}\text { Diğer meslekler (araştırmacı olmayan } \\
\text { mimar, mühendis, doktor vb.) }\end{array}$ \\
\hline \multirow[t]{3}{*}{$\begin{array}{l}\text { ÜNLÜ KİşI / LİDER } \\
\text { (Famous Person/ } \\
\text { Leader) }\end{array}$} & $\begin{array}{l}\text { AKADEMISYEN / BİLIM İNSANI } \\
\text { (Academician/Scientist) }\end{array}$ & Bilim insanı \\
\hline & & Filozof \\
\hline & & Kaşif \\
\hline
\end{tabular}




\begin{tabular}{|c|c|c|}
\hline & & Mucit \\
\hline & & Öğretim Üyesi / Profesör \\
\hline & & Öğretmen \\
\hline \multirow[t]{3}{*}{$\begin{array}{l}\text { ÜNLÜ Kișí / LiDER } \\
\text { (Famous Person/ } \\
\text { Leader) }\end{array}$} & ASKER / POLIS (Soldier /Police) & Asker \\
\hline & & Fatih \\
\hline & & Kumandan \\
\hline $\begin{array}{l}\text { ÜNLÜ Kişi̇ / LiDER } \\
\text { (Famous Person/ } \\
\text { Leader) }\end{array}$ & BÜROKRAT (Bureaucrat) & Bürokrat/Memur \\
\hline \multirow[t]{11}{*}{$\begin{array}{l}\text { ÜNLÜ Kiși̇ / LİEER } \\
\text { (Famous Person/ } \\
\text { Leader) }\end{array}$} & DİNİ ŞAHIS (Religious Person) & Aziz/Azize \\
\hline & & Budist \\
\hline & & Cemaat Lideri \\
\hline & & Guru \\
\hline & & Haham \\
\hline & & İmam \\
\hline & & Melek Ad1 \\
\hline & & Misyoner \\
\hline & & Papaz/ Rahip/ Rahibe/ Piskopos \\
\hline & & Peygamber \\
\hline & & Tanrı adı \\
\hline \multirow[t]{2}{*}{$\begin{array}{l}\text { ÜNLÜ KİŞ̇ / LİDER } \\
\text { (Famous Person/ } \\
\text { Leader) }\end{array}$} & $\begin{array}{l}\text { HALK KAHRAMANI / KAHRAMAN } \\
\text { (Folk Hero/ Hero) }\end{array}$ & Halk Kahramanı \\
\hline & & Mitolojik kahraman \\
\hline \multirow[t]{7}{*}{$\begin{array}{l}\text { ÜNLÜ KIŞ̦i / LİDER } \\
\text { (Famous Person/ } \\
\text { Leader) }\end{array}$} & SANATÇI (Artist) & Dansçı \\
\hline & & Mimar \\
\hline & & Müzisyen \\
\hline & & Ressam \\
\hline & & Şair \\
\hline & & Tiyatrocu/Oyuncu/Yönetmen \\
\hline & & Yazar \\
\hline \multirow[t]{6}{*}{$\begin{array}{l}\text { ÜNLÜ Ki̇şi / Li்ER } \\
\text { (Famous Person/ } \\
\text { Leader) }\end{array}$} & $\begin{array}{l}\text { SIYYASİ LİEER / POLİTiKACI } \\
\text { (Political Leader/ Politician) }\end{array}$ & Bakan \\
\hline & & Başbakan \\
\hline & & Cumhurbaşkani/ Devlet başkanı \\
\hline & & Hükümdar / Kral / Kraliçe \\
\hline & & Siyasetçi / Politikacı \\
\hline & & Tarihi Lider \\
\hline \multirow[t]{2}{*}{$\begin{array}{l}\text { ÜNLÜ KIŞ் / LiDER } \\
\text { (Famous Person/ } \\
\text { Leader) }\end{array}$} & $\begin{array}{l}\text { ÜNIVERSITE KURUCUSU / BAĞIŞÇISI } \\
\text { (Founder / Benefactor) }\end{array}$ & İşadamı \\
\hline & & Üniversite Kurucusu / Bağışç \\
\hline
\end{tabular}

